The Productivity of Agricultural Credit in India

Sudha Narayanan

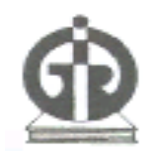

Indira Gandhi Institute of Development Research, Mumbai January 2015

http://www.igidr.ac.in/pdf/publication/WP-2015-01.pdf 


\title{
The Productivity of Agricultural Credit in India
}

\author{
Sudha Narayanan \\ Indira Gandhi Institute of Development Research (IGIDR) \\ General Arun Kumar Vaidya Marg \\ Goregaon (E), Mumbai- 400065, INDIA
}

Email(corresponding author): sudha@igidr.ac.in

\begin{abstract}
This study examines the nature of the relationship between formal agricultural credit and agricultural GDP in India, specifically the role of the former in supporting agricultural growth, using state level panel data covering the period 1995-96 to 2011-12. The study uses a mediation analysis framework to map the pathways through which institutional credit relates to agricultural GDP relying on a control function approach to tackle the problem of endogeneity. The findings from the analysis suggest that over this period, all the inputs are highly responsive to an increase in institutional credit to agriculture. A $10 \%$ increase in credit flow in nominal terms leads to an increase by $1.7 \%$ in fertilizers $(N, P, K)$ consumption in physical quantities, $5.1 \%$ increase in the tonnes of pesticides, $10.8 \%$ increase in tractor purchases. Overall, it is quite clear that input use is sensitive to credit flow, whereas GDP of agriculture is not. Credit seems therefore to be an enabling input, but one whose effectiveness is undermined by low technical efficiency and productivity. Notwithstanding these aggregate findings detailed microstudies would be necessary to provide insights into this issue.
\end{abstract}

Keywords: agricultural credit, growth, control function, elasticity, India

\section{JEL Code: Q10, Q14}

\section{Acknowledgements:}

This study was funded by the Research and Development (R\&D) fund of the Department of Economic Analysis and Research (DEAR), NABARD. I thank Dr. Harsh Kumar Bhanwala, Chairman, NABARD, Dr.Prakash Bakshi, Former Chairman, NABARD, Dr.R.N.Kulkarni, Dr.M.V.Ashok, Dr.Satyasai, the DEAR team at NABARD and Dr.S.Mahendra Dev for their support advice and inputs at various stages of this work. Garima Dhir provided valuable research assistance. Andaleeb Rahman, Krushna Ranaware, Sowmya Dhanraj, Sanjay Prasad, Sumit Mishra and others assisted in putting together the dataset used for this study. This work has benefitted immensely from Nirupam Mehrotra's inputs and insights into the various issues relating to the role of credit in Indian agriculture. I also thank all the participants of seminars on July 4, 2013 and November 14, 2014 at DEAR, NABARD and Pallavi Chavan of the RBI. A number of their suggestions have been incorporated in this paper. All remaining errors and omissions are however mine. 


\title{
The Productivity of Agricultural Credit in India
}

\author{
Sudha Narayanan ${ }^{1}$
}

\begin{abstract}
This study examines the nature of the relationship between formal agricultural credit and agricultural GDP in India, specifically the role of the former in supporting agricultural growth, using state level panel data covering the period 1995-96 to 2011-12. The study uses a mediation analysis framework to map the pathways through which institutional credit relates to agricultural GDP relying on a control function approach to tackle the problem of endogeneity. The findings from the analysis suggest that over this period, all the inputs are highly responsive to an increase in institutional credit to agriculture. A $10 \%$ increase in credit flow in nominal terms leads to an increase by $1.7 \%$ in fertilizers $(\mathrm{N}, \mathrm{P}, \mathrm{K})$ consumption in physical quantities, $5.1 \%$ increase in the tonnes of pesticides, $10.8 \%$ increase in tractor purchases. Overall, it is quite clear that input use is sensitive to credit flow, whereas GDP of agriculture is not. Credit seems therefore to be an enabling input, but one whose effectiveness is undermined by low technical efficiency and productivity. Notwithstanding these aggregate findings detailed microstudies would be necessary to provide insights into this issue.
\end{abstract}

Keywords: agricultural credit, growth, control function, elasticity, India

JEL Classification Q10, Q14

${ }^{1}$ Assistant Professor, IGIDR, Mumbai.sudha@igidr.ac.in 


\section{ACKNOWLEDGEMENTS}

This study was funded by the Research and Development (R\&D) fund of the Department of Economic Analysis and Research (DEAR), NABARD. I thank Dr. Harsh Kumar Bhanwala, Chairman, NABARD, Dr.Prakash Bakshi, Former Chairman, NABARD, Dr.R.N.Kulkarni, Dr.M.V.Ashok, Dr.Satyasai, the DEAR team at NABARD and Dr.S.Mahendra Dev for their support advice and inputs at various stages of this work. Garima Dhir provided valuable research assistance. Andaleeb Rahman, Krushna Ranaware, Sowmya Dhanraj, Sanjay Prasad, Sumit Mishra and others assisted in putting together the dataset used for this study. This work has benefitted immensely from Nirupam Mehrotra's inputs and insights into the various issues relating to the role of credit in Indian agriculture. I also thank all the participants of seminars on July 4, 2013 and November 14, 2014 at DEAR, NABARD and Pallavi Chavan of the RBI. A number of their suggestions have been incorporated in this paper. All remaining errors and omissions are however mine. 


\section{The Productivity of Agricultural Credit in India}

\section{Introduction}

The decades since 1990 have been challenging times for Indian agriculture. Growth rates of agricultural Gross Domestic Product (GDP) have been languishing and the traditional crop sectors have seen declining profitability. This has pushed policy makers to direct special attention to addressing some of the pressing concerns confronting Indian agriculture. Institutional credit has been an important lever in this effort. Indeed, as many as three major policy initiatives focussed on institutional credit have been implemented since 2000 to bolster the agricultural sector. The first policy initiative, introduced in 2004-05, was to double the volume of credit to agriculture over a period of three years (to 2006-07), relative to the 2004-05 base to expand the reach of formal finance. Close on its heels came the Agricultural Debt Waiver and Debt Relief Scheme (ADWDRS) 2008, in response to the persistent problem of indebtedness and to alleviate financial pressures faced by the farmers. The interest rate subvention was then introduced in 2010-11 with the stated goal of providing incentives for prompt repayment of loans, partly to address the perceived fallout of the ADWDRS, that it had somehow vitiated the repayment culture. All three measures have contributed, both explicitly and implicitly, to burgeoning institutional lending to agriculture in the last decade. ${ }^{2}$

Despite the significance of these interventions, very little is known regarding the outcomes, in particular, whether institutional credit has had the intended impact on agricultural growth. Existing commentaries focussing on this period point out the poor correlation between the two (Chavan and Ramakumar, 2007 for example). In this context, this research project aims to understand the extent to which, if at all, growing institutional credit to agriculture supports growth in the sector. What is its precise role and through what pathways does it support agriculture? These questions assume particular significance in the context of recent speculation that agricultural credit might not entirely flow to agriculture or and that there is a significant spillover to other sectors (Chavan, 2009; Burgess and Pande, 2005 and Binswanger and Khandker, 1992). Some ask if formal credit a 'sensible' way to support agriculture in India. While answers to this question are perhaps addressed best through detailed microstudies, it is also possible to elicit patterns and relationships between agricultural credit and agricultural GDP using secondary data. This study uses secondary data to examine four specific questions: How productive is institutional credit to the agricultural sector? What has been the trend since mid-1990s? What are the pathways through which credit impacts agriculture? How, if at all, have these pathways changed over the years? Using detailed state level data for the period 1995-2012, we analyze the possible impact of credit on agricultural GDP using multiple methods, using a control function approach. We also analyse the potential pathways through which institutional credit can influence agricultural growth, focussing on the responsiveness of input demand to institutional credit flow in some detail. An aggregate analysis of this nature necessarily has severe limitations and needs to be interpreted with care but can serve to complement our understanding of the productivity of agricultural credit in India.

\footnotetext{
2 There is evidence to suggest that the institutional lending to agriculture might have picked up since 2000 , even before the doubling of credit in 2004-05 (Chavan and Ramakumar, 2007).
} 
The paper is organized as follows. The following section (Section 2) provides the context of agriculture and credit in recent times, underscoring the motivation for this study. Section 3 reviews the empirical evidence on the productivity of rural credit in India, focussing on secondary data analysis at the aggregate level (state or national). Section 4 provides a conceptual framework for the present analysis. Section 5 then discusses the empirical strategies adopted in this work to tackle some inherent econometric issues that pose problems for establishing a causal relationship between credit and agricultural GDP. The section discusses the data used for the analysis and also outlines the scope and limitations of these approaches. Section 6 is devoted to the results from the econometric exercise and discusses the findings at length. The concluding section 7 closes with some remarks on the study and the way forward.

\section{Characterizing Agriculture and Institutional Credit since the 1990s.}

Both the structure of agriculture and the nature of institutional credit have been undergoing a rapid change since the 1990s but became especially pronounced since 2000. Initiatives to expand the reach of formal credit has been a goal pursued consistently in the past mainly by designating agriculture as a priority sector for lending. The introduction of schemes such as the Kisan Credit Card (KCC) scheme in 1998-99 aimed to provide farmers with adequate and timely credit support from the banking system for agriculture and allied activities in a flexible and cost-effective manner.

Three major policy initiatives in recent years have come to define the context of institutional credit to agriculture in India, as outlined in the introduction. The first policy introduced in 2004 sought to double the volume of agricultural credit relative to what it was in 2004-05, over a period of three years. Since then, the actual credit flow has consistently exceeded the target (Government of India, 2012). Against a credit flow target of Rs.3,25,000 crore during 2009-10, the achievement was Rs.3,84,514 crore, forming 118 percent of the target. The target for 2010-11 was Rs.3,75,000 crore while the achievement on March, 2011 is Rs.4,46,779 crore (Government of India ,2013). A second policy involved the waiving of agricultural debt for small farmers and an opportunity for one time settlement for others. ${ }^{3}$ Close on its heels, an interest subvention scheme was introduced to reward prompt repayment of loans, widely perceived has having been vitiated by the debt waiver scheme. Under the existing interest subvention scheme, farmers get short-term crop loans at seven per cent interest. If the loan to the bank is promptly paid then the effective rate of interest to the farmer works out to four per cent a year due to the additional interest subvention. ${ }^{4}$ Interest subvention scheme for short-term crop loans to be continued scheme extended for crop loans borrowed from private sector scheduled commercial banks. Together, these interventions have both explicitly and implicitly transferred large amounts to the agricultural sector. Although the increasing trend of institutional credit flow might have begun in 2000 itself (Ramakumar and

\footnotetext{
${ }^{3}$ As per the provisional figures, a total of 3.01 crore small and marginal farmers and 67 lakh 'other farmers' have benefited from the Scheme involving debt waiver and debtrelief of Rs.65,318.33crore (Government of India, 2013).

${ }^{4}$ From kharif 2006-07, farmers are receiving crop loans upto a principal amount of 3 lakh at $7 \%$ rate of interest. In the year 2009-10, Government provided an additional 1\% interest subvention to those farmers who repaid their short term crop loans as per schedule. This subvention for timely repayment of crop loans was raised from $1 \%$ to $2 \%$ in 2010-11, further 3\% from the year 2011-12. Thus the effective rate of interest for such farmers will be $4 \%$ p.a. (Government of India, 2013).
} 
Chavan, 2007), credit flow in recent years have stood out for its magnitude, if not for reversing the trend of the 1990s.

For example, ground level credit flow as a ratio of the total value of paid out inputs in agriculture and allied sector has increased from an average of 21\% in 1995-96 to 2003-04 to 69\% during the period 2004-05 to 2011-12 (See Appendix 1 for growth in the number of accounts) . As of 2011-12, institutional credit is equal to $85 \%$ of paid out inputs. If all institutional agricultural credit were directed to inputs, this increasing share is suggestive of credit outstripping the increasing costs and perhaps crowding out informal borrowing in the aggregate. However, in reality given the fungibility of credit, this is not self-evident.

Figure 1: Ratio of institutional credit to the value of agricultural inputs

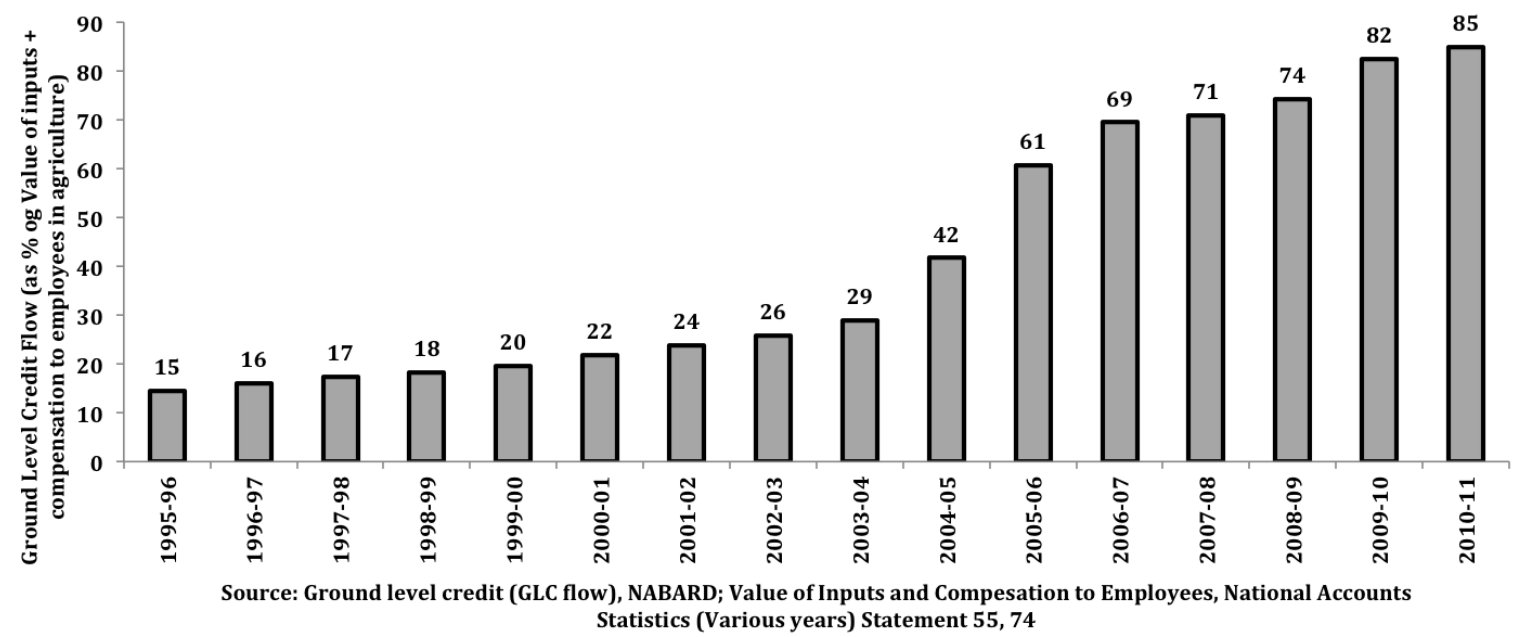

Alongside the significant increase in the total credit flow into agriculture, the nature and source of credit have also seen significant shifts. Indirect finance has, for instance, accounted for an increasing share of total credit and in terms of the type of institution that provide credit, commercial banks have been growing in importance as a source (Figure 2). As observers point out the definition of indirect finance (and what constituted permissible lending avenues) have widened in scope (Ramakumar and Chavan, 2007, for example) accounting for the apparent increases. These tend to vary across states and over time.

Parallel to transformation in the structure of agricultural credit is the equally rapid transformation of the agricultural sector. The past two decades have seen an increase in the share of livestock relative to crops, with extraordinary growth in poultry and dairy sectors. The crop sector has seen significant diversification, to high value commodities, to horticulture for example. At the same time, the contextual constraints of agriculture have also been significant issues. Rising costs of inputs, tightening labour markets, increasing wages and a host of environmental constraints such as water and soil quality degradation have resulted in plateauing yields and thinning profit margins. The past decade has seen increasing mechanization as evidence by the sale of machinery (Figure 3) as well as in the machine hours employed per hectare (Figure 4). In particular, it is evident from state level data on the Cost of Cultivation studies in India that the 
mechanization process has replaced animal and draught power while decline in human labour inputs into agriculture have been less by comparison (Figure 4). ${ }^{5}$

Figure 2: Source-wise Credit Disbursements
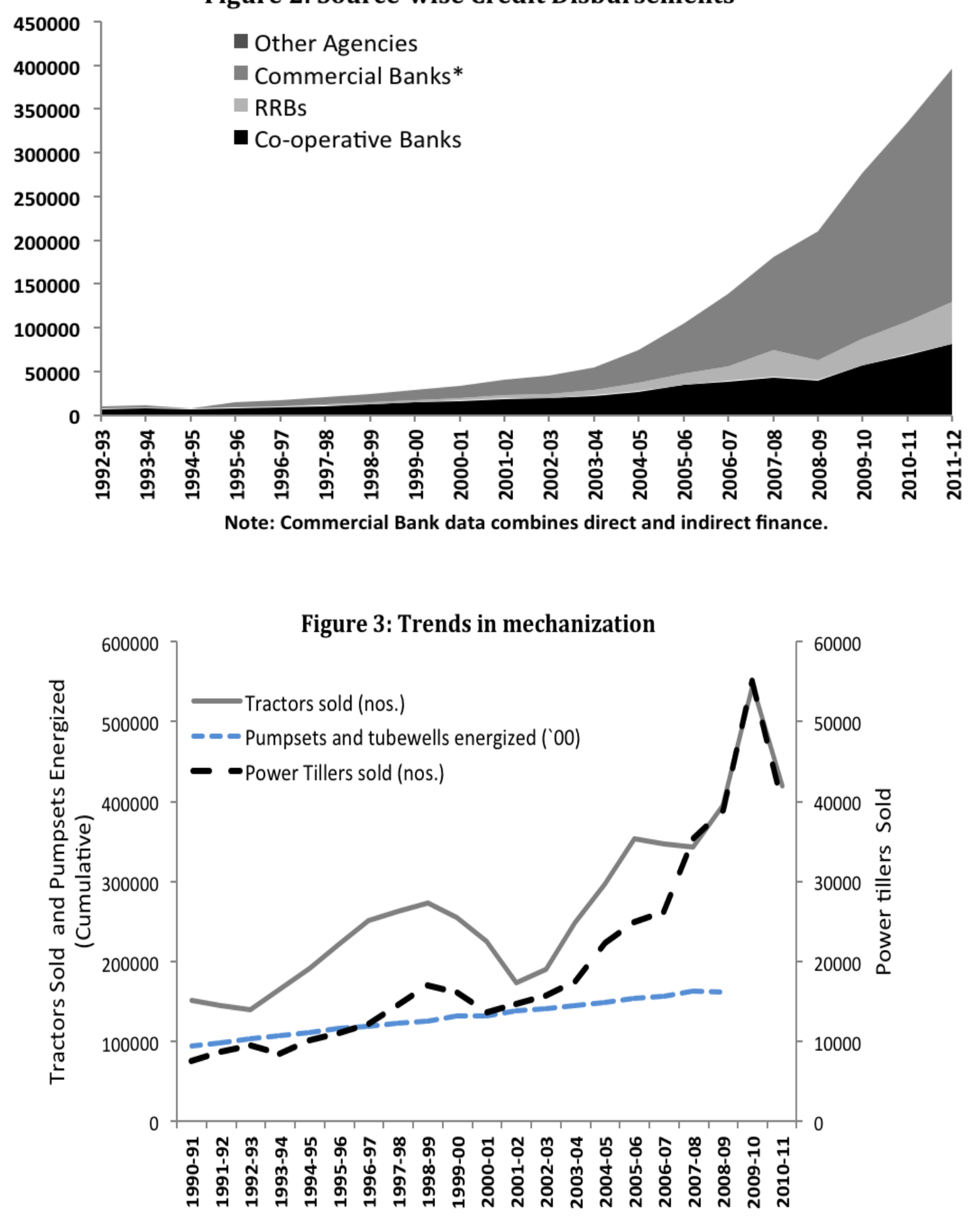

${ }^{5}$ For more details on cost of cultivation studies in India, see http://eands.dacnet.nic.in/Cost of Cultivation.htm. Accessed January, 2014. 


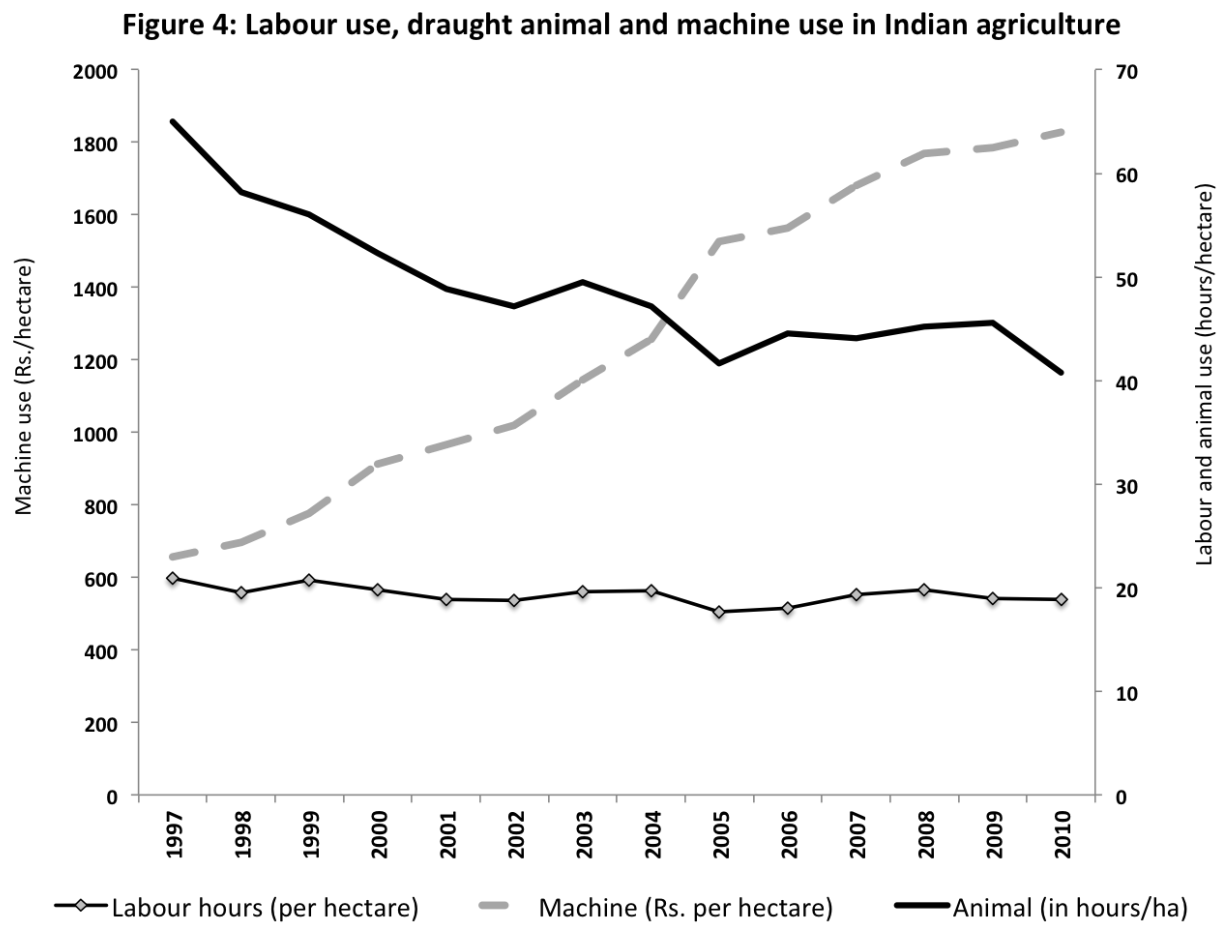

Source: Cost of Cultivation in India (several years). The All India average is the weighted avearge across crops and states, where the weights are area sown under each crop within state and the net sown area across states.

There is now limited evidence that despite the widespread notion of a crisis, Indian agriculture might be more productive but that these improvements as represented by Total Factor Productivity (TFP) is coming from certain states (in the south and west) and certain sectors (such as horticulture and livestock). ${ }^{6}$ Other evidence similarly suggests that productivity improvements is marked only in a few states (Chaudhari, 2013). Improvements in efficiency are low for a majority of states and might have in fact declined in several states implying the presence of potential gains in production even with existing technology.

The links that institutional credit has to agricultural productivity and growth are still somewhat underresearched. Figure 5 plots the ratio of agricultural GDP to credit flow over the period 1996-2011 for the various states. It is apparent that notwithstanding the variation across states, the ratio for the country as a whole has been declining over the past 15 years and is now close to one on average. These patterns appear to indicate that although credit is contributing to a larger share of the value of purchased inputs, the relationship between agricultural GDP and agricultural credit are possibly weak, raising important questions on the role of agricultural credit.

\section{Figure 5: The Ratio of Agricultural GDP and Credit for major states (1996-2011)}

${ }^{6}$ See Rada(2013) for a recent analysis of Total Factor Productivity in India. Results suggest renewed growth in aggregate TFP growth despite a slowdown in cereal grain yield growth. TFP growth appears to have shifted to the Indian South and West, led by growth in horticultural and livestock products over the period 19802008. 


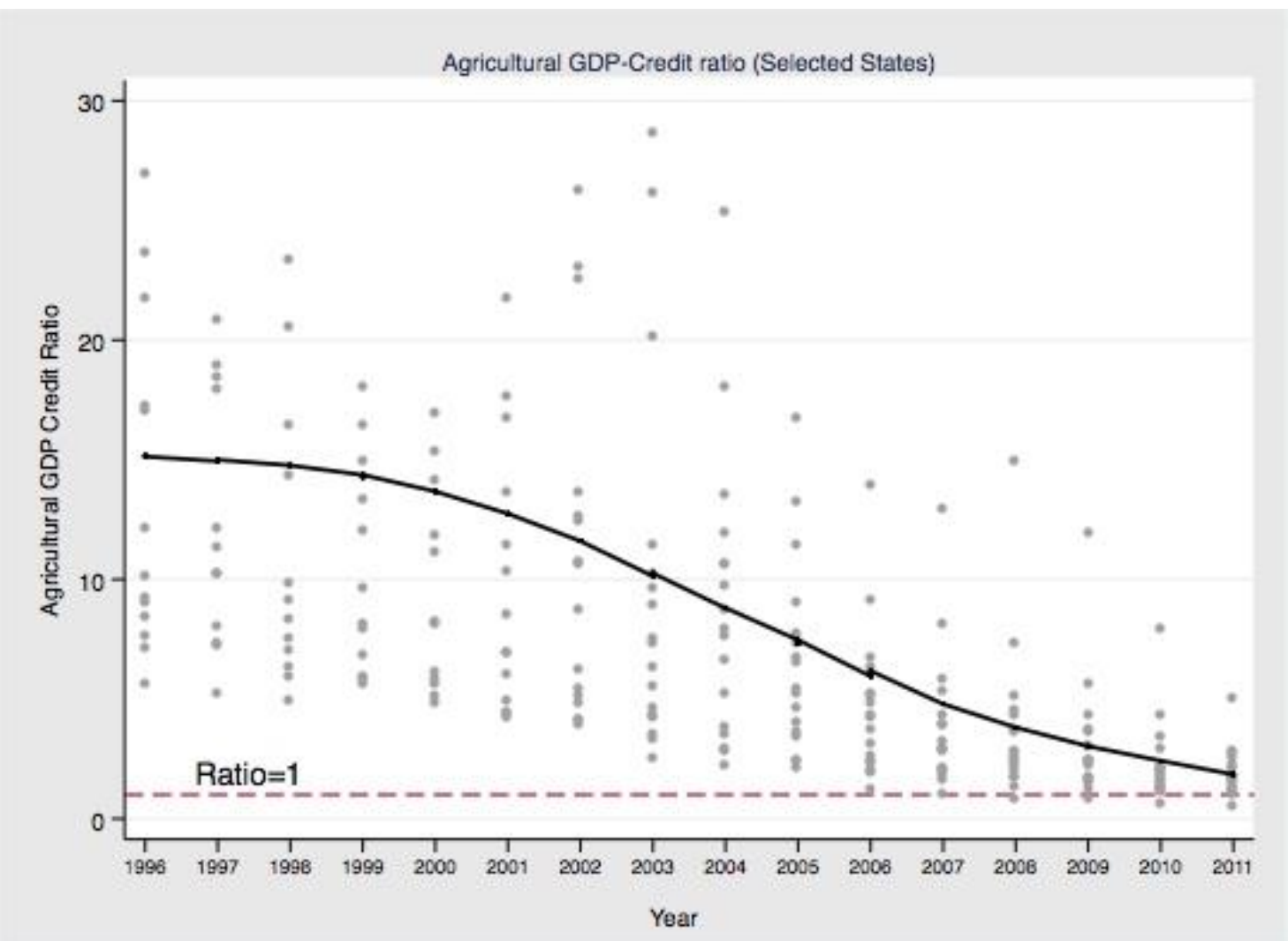

Notes: The scatter points represent the ratio of agricultural GDP and credit outflow and the line represent the lowess fit, i.e. locally weighted scatterplot smoothing.

\section{Empirical Evidence on the Productivity of Institutional Credit in India}

The best known study of the impact of formal rural credit in the context of India is by Binswanger and Khandkher (1992) who found that rural credit has a measurable positive effect on agricultural output. Cooperative credit advanced has elasticity with respect to output of 0.063 . It is larger than the elasticity of crop output with respect to predicted overall rural credit which is near 0.027, but not precisely estimated. The estimate for the impact of commercial bank branches on output is more precisely estimated at 0.02 . Others suggest that the effect on output is either nonexistent, for example Burgess and Pande (2005) who claim that the increase in output due to formal credit comes entirely from increases in non-farm output, or have been negligible. ${ }^{7}$ Others show that there is a positive association between credit and agricultural output but that this varies cross states and further that there is a positive association between the number of persons with accounts and agricultural output suggesting the financial inclusion could impact agricultural output positively (Das, et al, 2009). ${ }^{8}$ However a dynamic panel data estimation of this relationship does

${ }^{7}$ The estimates suggested that a one percent increase in the number of rural banked locations reduced rural poverty by roughly 0.4 percent and increased total output by 0.30 percent. The output effects are solely accounted for by increases in non-agricultural output - a finding which suggests that increased financial intermediation in rural India aided output and employment diversification out of agriculture.

8There are two models that have been estimated in the literature - fixed effects and random effects. The fixed effects model assumes that there is an unobserved time independent effect for each state of India and this effect could be correlated with other explanatory variables. The Hausman test helps decide whether to 
not yield a statistically significant relationship at the state level. A district level panel for 2001-06 for four states however reveals that direct agricultural credit has a positive and immediate impact on agricultural output, and the number of account relating to indirect agricultural credit has a positive impact but with a year's lag. More recent work using time series techniques without modeling the underlying structure indicate that the elasticity of real agricultural GDP with respect to institutional credit to agriculture (from commercial banks, cooperatives and RRBs) is 0.22 with a one-year lag (Subbarao, 2012). ${ }^{9}$ In contrast to the somewhat ambivalent findings on the association between agircultural credit and output, there appears to be consensus that formal agricultural credit has an important effect on the use of inputs. Bhalla and Singh (2010) demonstrate in their cross sectional analysis using data for 2003-06 that the elasticity of demand for inputs with respect to credit is quite significant. At the all India level, credit elasticities for use of fertilisers, tractors and tubewells hovered around 0.85 suggesting that 10 per cent increase in supply of direct institutional credit to the farmers to leads to 8-9 per cent increase in use of fertiliser, tractors and tubewells in long run. Their finding comes from a simple model that regresses the logarithm of inputs per unit of output on logarithm of institutional credit. They find that these elasticities vary across regions and credit elasticities are exceptionally very high for tractors, tubewells and irrigation for the technologically backward eastern region. Bhalla and Singh (2010) then suggest that institutional credit is indispensable for these regions with low input and investment in agriculture. Binswangerand Khandker (1992) point out that institutional growth and higher lending volumes lead to modest increases in aggregate crop output but sharp increases in the use of fertilizers and in investments in physical capital and, substantial reductions in agricultural employment. They conclude on that basis that expansion of credit has, therefore, led to the substitution of capital for agricultural labor.

These two studies emphasize the multiple pathways in which formal agricultural credit impacts production and this is well recognized by now (see Sriram 2007, for example). If one is to understand this linkage in all its complexity, one needs a detailed construct of these relationships.

\section{Conceptualization of the Role of Formal Credit}

The fundamental attribute of credit implies that it serves as an intermediate input and does not directly enter as an input into agricultural production. It is therefore an enabling input. On account of this, it plays a complex role in farmers' production decisions, unlike physical inputs that have a more transparent relationship with the levels of output.

The impact of agricultural credit on agricultural production, efficiency and productivity could potentially occur through multiple channels. A simple conceptualization identifies three pathways through which formal credit can influence outcomes (Figure 6). First, formal credit can be used to purchase inputs over the cropping season, enabling a farmer to maximize the yield from the cultivated area, given a level of capital stock. This channel represents a direct and within-season impact on production. Second, formal credit can be used to make investments in irrigation facilities, machines and draught animals that represent the use of credit for building up capital stock to support agricultural production. This second channel typically impacts production with a time lag.

estimate a fixed effects model or a random effects model. The random effects model assumes that the unobserved effect is uncorrelated with all the explanatory variables.

${ }^{9}$ The model regresses $\ln$ (AGDP) on $\ln$ (Acredit(-1)), where AGDP = GDP from agriculture and allied activities at constant prices and Acredit = Credit for agriculture and allied activities deflated by GDP deflator with one year lag. Other studies of this type include Ghosh (2010), Pavaskar, et al. (2011). 
Both of these represent a "liquidity effect" (Binswanger and Khandkher, 1992) since they relieve a farmer's credit constraint and enables purchase of critical inputs to support production. Third, formal credit is often used to replace informal credit associated with high interest burden. Anecdotal evidence suggests that farmers often borrow from formal sources to pay off high interest loans taken from money lenders. This has the effect of relieving credit constraints, reducing the interest burden and indebtedness. Existing economic literature on wealth effects and risk aversion suggests that this often enables farmers to make decisions that increase profitability and efficiency. Even when formal credit is diverted to consumption, there could be an implicit wealth effect that impacts farmer's production decisions. This last channel, which incorporates a "consumption smoothing" effect is is often difficult to capture.

Collectively, formal agricultural credit can be regarded as having two kinds of impacts first, it could enable a farmer to move to the production frontier so that given prevalent technology, a farmer is using levels of inputs that enable him/her to produce at the frontier, from among many feasible combinations of crops. Second, it could enable a farmer to move on to a superior production frontier, so that given a level of inputs, the farmer is able to produce more of one or more of the crops. The first is represented as a move from within the production possibility set to the frontier (constituting efficiency improvement) and the second is represented as a shift of the frontier itself (constituting productivity improvement). The impact of formal agricultural credit on agricultural output conflates these two aspects of productivity and efficiency effects.

\section{Figure 6 : Schematic Representation of Pathways}

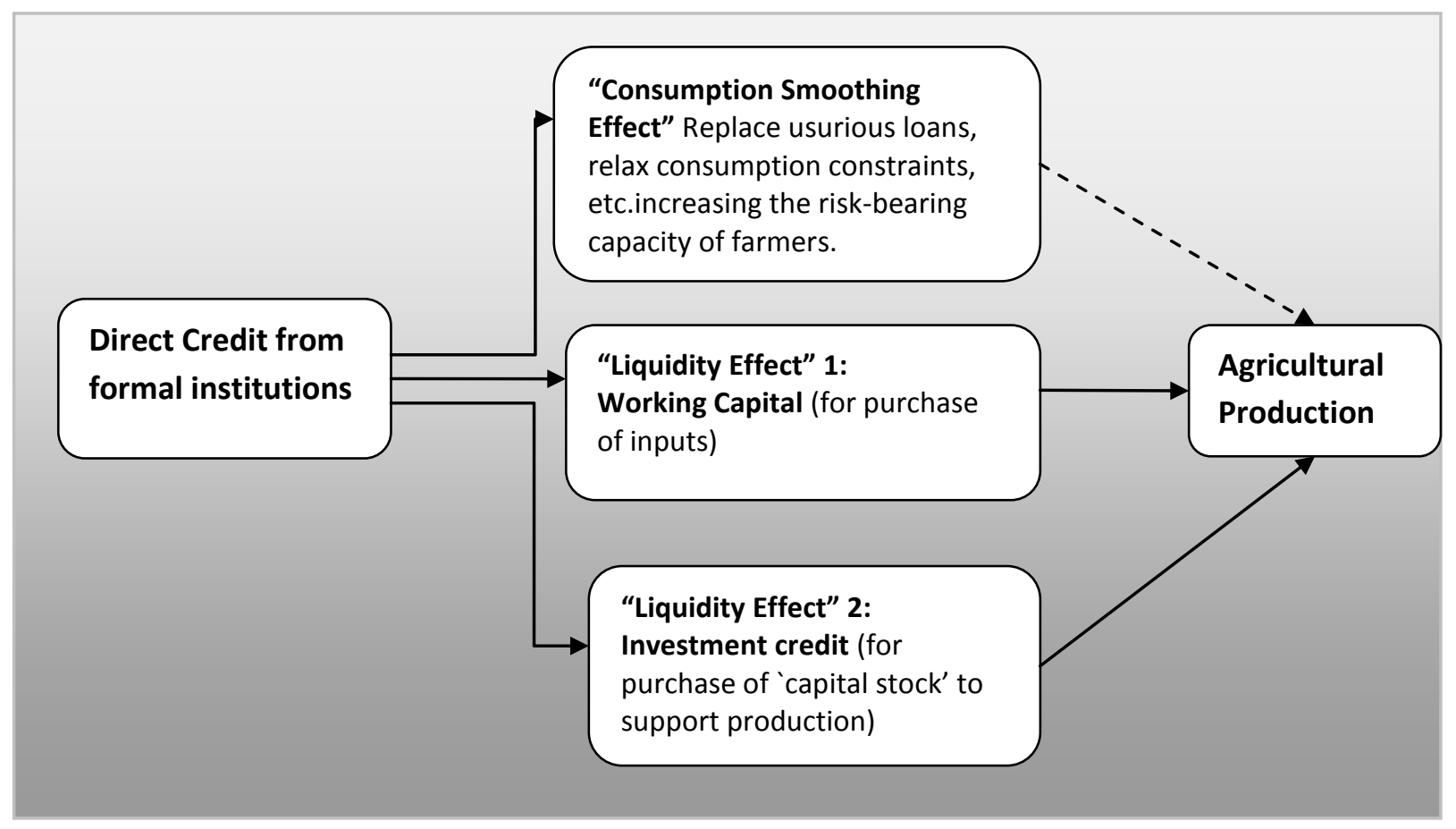




\section{Empirical Strategy}

\section{a. The Challenges}

Empirically, these effects are difficult to entangle. While a separation of these effects and pathways are ideally studied at the household level, this logic can be extended to an aggregate level by choosing empirical counterparts that represent these dimensions at the state or district level, with important caveats. Aggregation often masks a lot of the heterogeneity and complexity of the ways in which formal agricultural mediates production processes. The distribution of credit among farmers or farmer groups is often uneven and is not taken into account when in an aggregate analysis. Similar problems occur with aggregating over all the crops and commodities, which masks the differential impacts and relative importance of credit. While this study is cognizant of these issues, data limitations allow only an aggregate-level analysis.

Several methodological and data challenges persist in estimating the impact of formal agricultural credit on output, especially at the aggregate level. Firstly, informal credit which forms a major source of credit is something of a black box with virtually no data available on its quantum or how it is used. The fungibility of credit too poses difficult problems for research since it makes short and long term credit indistinguishable at the farmers' end. Similarly there could be spillovers into non-farm sector that are unknown to the lenders and to researchers. Direct and Indirect finance might also not be watertight categories so that it could be the case that direct credit to the farmer is in fact used for ancillary activities that support agriculture. All of these make it hard to pin down the precise nature of relationship between credit and agriculture. Further, the dynamic effects are difficult to capture since credit flow in a particular year might yield cumulative benefits over several years. This is particularly difficult to model. The other major challenges stem from data constraints at the state level. Existing data for variables of interest are not often available for all the states and for all the years, forcing us to confine the analysis to the states for which we have complete data for the period of focus.

The empirical challenges of studying the relationship between formal agricultural credit and output at an aggregate level are best described by Binswanger and Khandker (1992). The first problem is the joint determination of both observed formal credit to agriculture and aggregate output. The second problem emanates from the absence of data on informal credit, which makes it difficult to capture the impacts of formal credit that might work through reduced informal borrowing, and not factoring this might yield the estimates that reflect the true effect of formal credit. Credit advanced by formal lending agencies such as banks is an outcome of both the supply of and demand for formal credit. The amount of formal credit available to the farmer, his/her credit ration, enters into his/her decision to make investments, and to finance and use variable inputs such as fertilizer and labor. The third econometric problem arises because formal agriculture lending is not exogenously given or randomly distributed across space. Ways to be able to address some of these issues are central concerns of this study. 


\section{b. Methodology}

To parse this complex relationship given the limitations of data, a combination of three approaches are used (Box 1). The first is a simple model that regresses agricultural GDP on credit flow using state level data. This is a catchall approach that cannot comment on the pathways or provide a causal interpretation. The second method estimates a hybrid profit-production function that regresses agricultural GDP on a vector of relevant inputs, prices and agricultural credit for the same year. This is a direct approach to estimating the relationship between credit and agricultural GDP in reduced form. The possible endogeneity of credit is addressed by the use of a control function approach where a regression function is estimated that identified and then "controls" for the endogenous component of observed credit flow (Imbens and Wooldridge, 2007). The coefficient on credit in this case captures one dimension of impact of credit that is not mediated through inputs. The third method is perhaps the most comprehensive and models the pathways approach in what is referred to as a mediation analysis framework, where inputs are regarded as mediating the relationship between institutional credit and agricultural GDP (Preacher and Hayes, 2008). Here, a set of regressions estimates input demand as a function of credit, among other things and controlling for endogeneity of credit (indirect effect), and the hybrid production-profit function as a function of inputs and credit, recognizing that credit can also have direct effect on GDP. The coefficients representing the responsiveness of input use to institutional credit are therefore used as components to construct the total impact of agricultural credit on agricultural GDP (Preacher and Hayes, 2008). The impact of credit on agricultural output is thus derived as the sum of the contribution of credit to the use of specific inputs, capital or the cropping pattern, weighted by the contribution of these to the total value of agricultural production. These are estimated in a Seemingly Unrelated Regression Equations (SURE) framework that acknowledges the potential interrelationship between these variables and the fact that they might be jointly

Box 1: The Three Approaches

Method 1: The Simple Model using state level data and dividing into time periods in nominal terms as well as accounting for prices.

Method 2: The Direct Approach that regresses agricultural GDP on various inputs (fertilizers, tractors pumpsets), prices, rainfall, public expenditure on agricultural, including credit flow and the estimated endogenous component of credit or the "control" variable.

Method 3: The Pathways Approach that works on three stages - credit market, input demand functions and value of GDP function, estimated in a SURE framework for panels and incorporating the control variable. determined. Appendix 2 contains a representation of the models estimated.

For all three methods we use state-level data to estimate the relevant parameters of interest for India as a whole. The analysis pertains to the time period 1995-96 to 2011-12, for which the data is complete. Further, we also perform an analysis for two sub-periods first (1995-96 to 200304) and post doubling (2004-05 to 2011-12). In all the methods, we make the assumption of constant elasticity of demand, which is in fact a non-trivial assumption, but one that is typical of studies of this kind.

As mentioned earlier, the chief methodological challenge involves dealing with the the issue of endogeneity of observed credit. There are several approaches to deal with this. One approach to tackle the endogeneity of observed volumes of credit is to use the predicted supply of credit at the state level, following Binswanger and Khandker (1992) or to use lagged credit that is correlated with current year credit. Each of these involves a set of defensible assumptions. The latter approach 
however creates problems because there could typically be lagged response of agricultural GDP which renders lagged credit an inappropriate instrument. In this study we use a control function approach to separate out the explained exogenous variation in the credit flow to agriculture from the unexplained and possibly endogenous component of credit flow and use the predicted residuals from the control function to control for endogeneity in the main set of regression equations (Imbens and Wooldridge, 2007). Appendix 2 provides more details on the approach and the regressions estimated. The standard errors for both models 2 and 3 are bootstrapped to account for the use of predicted variables as explanatory variables.

\section{c. Data Sources}

To implement this method, we use a data set that is more detailed than used in the literature till date. For all the major states in India details on credit, agricultural GDP, composition of the value of output in the agriculture and allied sector and variables relating to land under cultivation provide the key variables of interest. Data on physical quantities of Nitrogen, Phosphorus and Potassium fertilizers have been assembled as also pesticides (technical grade) as also tractors and pumpsets energized. Use of certified seeds in only available at the national level and is only used in explain agricultural GDP but not as a separate input since this cannot be done at the state level. Other state level variables representing the level of development include per capita State Domestic Product, percentage of villages electrified, the number of commercial bank branches. Prices are typically available at the all-India level, for the various inputs, power and fuel as well as output (food grains, etc.). State level wage rates are compiled and in the absence of annual data on labour inputs used, wage rates are expected to proxy labour use. We are also able to account for labour, machine and animal power intensity per hectare from Cost of Cultivation data at the state level. These are computed within state as the weighted average across crops (with weights being the area under different crops), and across states as the weighted average across states (with weights being the state's share of gross cropped area). While for labour and animal, we use hours per hectare, machine use data are in value terms. Appendix 3 provides details of the data used for the analysis and the sources. While data is not available for all the states for all the years, only those states and years for which all data was available are used in the analysis. Essentially, the data then consists of time series data for the major states so that the panel data framework is used to estimate the impact of credit on agricultural output at the national level, with state fixed effects. The models are estimated for the major agricultural states, since data is not complete for all the states.

\section{d. Scope and Limitations of the Study}

The scope of this effort will be limited to estimating the impact of formal credit from different institutions - cooperatives, rural and commercial banks - on agricultural output. The spillover effects of formal credit on the rural non-farm sector will not be addressed specifically, an issue that research suggests might be quite important (Pande and Burgess, 2005). Neither does this work address the implications of recent interventions in credit policy such as debt waiver; this is already studied elsewhere (Kanz, 2012; Cole, 2009). Another important area that is beyond the remit of this study is the fiscal implication of the system of disbursing formal rural credit. One could argue that to gauge the true impact of credit, one would have to account for the fiscal burden (or some notion of net benefit cost ratio) (Binswanger and Khandkerm 1992). In this work, the question of interest 
is to gauge whether or not direct formal rural credit impacts agricultural output, the extent to which it does so and the relative importance of the different pathways through which these effects occur.

\section{The Results \\ a. The Productivity of Credit: Credit Elasticity of Agricultural GDP}

The range of estimates obtained from the various methods suggest that the credit elasticity of agricultural GDP for the entire period $1995-96$ to $2011-12$ is 0.21 , i.e. a $10 \%$ increase in institutional credit flow to agriculture in current prices is associated with a $2.1 \%$ increase in agricultural GDP that year expressed in current prices (Table 1). This model controls for prices and hence account for inflation.

Compared with these results in the simple model (method 1), the estimated credit elasticity is 0.04 when the model controls for the use of inputs and a vector of input and output prices and for the possible endogeneity of credit through a control function approach (method 2). The structural model incorporating the pathways through which credit influences agricultural GDP (method 3) yields estimates of credit elasticity of 0.02 . But neither method indicates that these coefficients are statistically significant (Table 1 ).

The results from a period-wise disaggregate analysis is less conclusive. While the simple model suggests that the elasticity continues to be statistically significant but has weakened in the second period, the other two approaches, one that controls for prices and inputs and the other the captures the pathways suggest that the relationship between credit and agricultural GDP may have declined, but none of the estimated credit elasticity coefficients are statistically significant and hence on cannot reject the null that the responsiveness of agricultural GDP to credit has been zero.

At the state level, estimates of credit elasticity of agricultural GDP from the 'simple' model, the only feasible option given the data, vary mostly between 0.05 and 0.7 with several states show statistically insignificant elasticities (Table 2). Further, at the state level, the time trend of elasticity estimates varies across states. In some states the relationship appears to have strengthened post doubling (for example, in Tamil Nadu, Maharashtra and Gujarat) whereas for several others it has weakened (including for Himachal Pradesh, Rajasthan, Uttar Pradesh, Karnataka, Kerala, Chhattisgarh Madhya Pradesh, etc.). Punjab appears to show a consistently strong relationship between agricultural GDP and credit. Notwithstanding these variations, a striking feature in the relationship between agricultural GDP and credit flow is the pronounced convergence in the agricultural GDP-credit flow ratio suggesting that perhaps the marginal returns to credit might be equalizing across states (Figure 7). Appendix 6 provides some details of the regional imbalances in credit flow relative to the contribution of these regions to agricultural GDP.

Further clarity and insight can only be obtained through detailed case studies or primary surveys, owing to the paucity of state level data that precludes modeling efforts at the state level.This underscores the potential problems with aggregation and that observations on trends cannot be generalized. 
Table 1: Summary Results of the three models

\begin{tabular}{|c|c|c|c|}
\hline $\begin{array}{l}\text { Time period for which } \\
\text { elasticity of GDP with } \\
\text { respect to credit is } \\
\text { computed. } \\
\text { (1) }\end{array}$ & $\begin{array}{l}\text { Method } \\
\text { 1(Simple } \\
\text { Model) } \\
\text { (2) }\end{array}$ & $\begin{array}{l}\text { Method } 2 \text { (Direct } \\
\text { Approach using } \\
\text { Control Function } \\
\text { methods.) } \\
\text { (3) }\end{array}$ & $\begin{array}{c}\text { Method } 3 \\
\text { (Pathways approach } \\
\text { using Control } \\
\text { Function for credit) } \\
\text { (4) }\end{array}$ \\
\hline The Entire Period & $0.214^{* * *}$ & 0.036 & 0.210 \\
\hline Phase I & $0.266^{* * *}$ & -0.010 & 0.102 \\
\hline Phase II & $0.099 * * *$ & 0.138 & -0.030 \\
\hline
\end{tabular}

Notes:

(1) The Hausman Test suggests that the fixed effects model is appropriate. For Model 1, the Hausman chi-sqaured (1) $=15.51^{* * *}$

(2) Granger Causality tests indicate that agricultural credit Granger-causes agricultural GDP and not the other way.

(3) The Chow test for Method 1 indicates that the second phase coefficient is not statistically significantly different from that from the first period.

(4) Detailed results are available in Appendix 4 and 5.

(5) Standard errors for the control function approach are bootstrapped 200 times.

(6) The states included in this regression are Andhra Pradesh, Bihar, Chhattisgarh, Gujarat, Haryana, Himachal Pradesh, Jharkhand, Karnataka, Madhya Pradesh, Maharashtra, Orissa, Punjab, Rajasthan, Tamil Nadu, Uttar Pradesh, Uttarakhand, West Bengal. For new states, data since their inception are included.

(7) All models control for prices. 
Table 2: State-wise Credit Elasticity of Agricultural GDP under the Lag Model

\begin{tabular}{|c|c|c|c|c|}
\hline Census Code & State & Whole Period & Phase I & Phase II \\
\hline 1 & Jammu and Kashmir & $0.053^{*}$ & 0.151 & 0.002 \\
\hline 2 & Himachal Pradesh & $0.303^{* *}$ & $0.232^{* *}$ & 0.112 \\
\hline 3 & Punjab & $0.340^{* * *}$ & $0.522^{* *}$ & $0.129 * *$ \\
\hline 4 & Chandigarh & 0.047 & 0.016 & -0.011 \\
\hline 5 & Uttaranchal & 0.019 & $-0.103^{* * *}$ & -0.086 \\
\hline 6 & Haryana & $0.406^{* * *}$ & $1.900^{* * *}$ & -0.440 \\
\hline 7 & Delhi & 0.029 & -0.024 & -0.109 \\
\hline 8 & Rajasthan & 0.171 & $0.853^{* * *}$ & 0.060 \\
\hline 9 & Uttar Pradesh & $0.288^{* * *}$ & $-0.960 * *$ & 0.040 \\
\hline 10 & Bihar & -0.062 & $-0.427^{* * *}$ & $0.574^{*}$ \\
\hline 11 & Sikkim & $0.092^{* * *}$ & 0.029 & -0.030 \\
\hline 12 & Arunachal Pradesh & 0.035 & 0.044 & -0.004 \\
\hline 13 & Nagaland & -0.022 & -0.217 & -0.023 \\
\hline 14 & Manipur & $-0.048^{*}$ & $-0.073^{* *}$ & -0.061 \\
\hline 15 & Mizoram & $0.072^{*}$ & 0.092 & -0.119 \\
\hline 16 & Tripura & 0.013 & -0.147 & -0.001 \\
\hline 17 & Meghalaya & -0.000 & $-0.048^{*}$ & $0.065^{* * *}$ \\
\hline 18 & Assam & -0.006 & -0.018 & -0.005 \\
\hline 19 & West Bengal & 0.015 & $-0.866^{* * *}$ & 0.005 \\
\hline 20 & Jharkhand & $0.255^{* *}$ & 0.252 & -0.420 \\
\hline 21 & Orissa & $0.321^{* * *}$ & 0.421 & 0.028 \\
\hline 22 & Chhattisgarh & $0.376^{*}$ & $0.205^{* * *}$ & -0.054 \\
\hline 23 & Madhya Pradesh & $0.490^{* * *}$ & $0.555^{*}$ & -0.049 \\
\hline 24 & Gujarat & $0.574^{* * *}$ & 0.826 & $0.567^{* * *}$ \\
\hline 25 & Daman and Diu & - & - & - \\
\hline 26 & Dadra Nagar Haveli & - & - & - \\
\hline 27 & Maharashtra & 0.016 & -0.007 & $0.209^{*}$ \\
\hline 28 & Andhra Pradesh & $0.448^{* * *}$ & $1.046^{*}$ & 0.143 \\
\hline 29 & Karnataka & $0.278^{*}$ & $1.591^{* * *}$ & 0.039 \\
\hline 30 & Goa & -0.095 & -0.300 & 0.017 \\
\hline 31 & Lakshadweep & - & - & - \\
\hline 32 & Kerala & $0.325^{* * *}$ & $0.395^{* * *}$ & -0.033 \\
\hline 33 & Tamil Nadu & $0.355^{* * *}$ & 0.493 & $0.298^{* * *}$ \\
\hline 34 & Pondicherry & $0.187^{* *}$ & 0.069 & 0.133 \\
\hline 35 & Andaman and Nicobar Islands & -0.006 & $0.040^{*}$ & -0.070 \\
\hline
\end{tabular}

Notes: The state level elasticities are the slope coefficient from a regression of agricultural GDP on credit flow to agriculture, controlling for wholesale price index. States have been arranged according to census code. 
Figure 7: State-wise ratio of Agricultural Gross Domestic Product and Credit Flow (19962011)
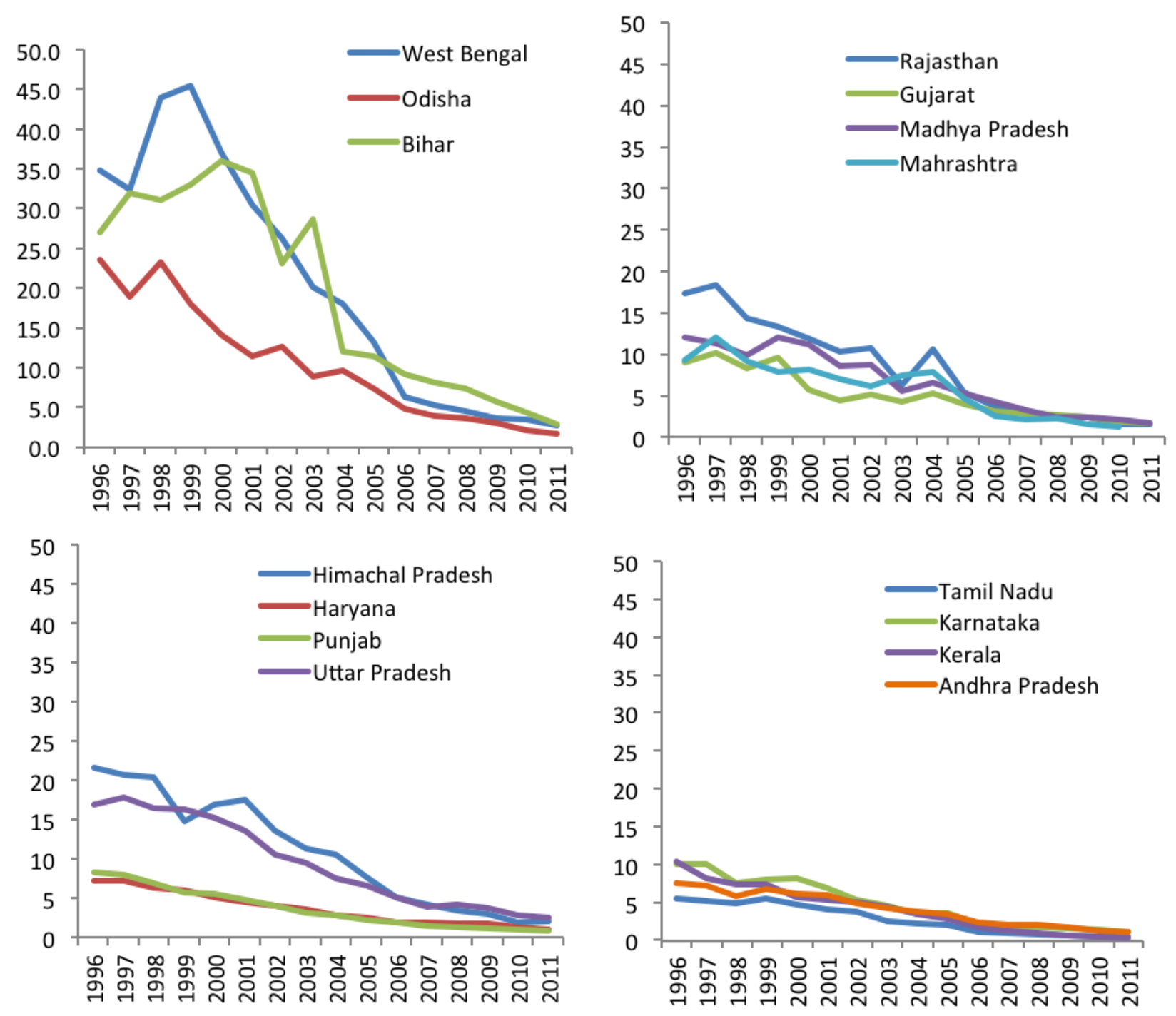

Notes: Only the major states have been included. 


\section{b. Pathways of "productivity": Input Demand and Credit Flow}

If credit is an enabling or mediating input, its impact on output and productivity operates through its influence on the level of purchased inputs, variable and fixed. A system of input demand functions is estimated as a Seemingly Unrelated Regression Equations (SURE), with credit as one of the explanatory variables along with the predicted residuals from the control function to account for the endogeneity of credit (Table 3). The inputs included are fertilizers (a total of Nitrogen, Phosphate and Potassic fertilizers), pesticides, tractors purchased and pumpsets energized annually. The other inputs include labour and animal power intensity as well as expenditure per hectare on machine use. Controls include other inputs like land, distinguished by type of irrigation, prices of inputs, prices of food articles, lagged wages of unskilled labour, government expenditure, lagged variable accounting for the structure of agriculture. Due to paucity of state level annual data, detailed information on other equipments are not available for inclusion; tractors are therefore a coarse proxy for equipment.10 So too with pumpsets, which represent one type of irrigation investment. Investments in drip and sprinkler irrigation, etc. are hard to capture for lack of data. The inclusion of government expenditure likely captures the subsidies offered for these irrigation investments. These results need to be interpreted with caution. The results (Table 1) suggest that over the entire period, institutional credit has a strong association with all inputs excepting pumpsets energized. A $10 \%$ increase in credit flow in nominal terms leads to an increase by $1.7 \%$ in fertilizers $(\mathrm{N}, \mathrm{P}, \mathrm{K})$ consumption in physical quantities, $5.1 \%$ increase in the tonnes of pesticides, $10.8 \%$ increase in tractor purchases. The credit elasticity of new pumpsets energized is however not statistically significant.

Interestingly, there appears to be a marked shift in the pathways between the first and second phases. Whereas in the first phase, institutional credit seems to have been channelled into purchase of variable inputs such as fertilizers, in the second phase, credit seems to be directed to investments in tractors. This is consistent with the popular perception that high labour costs and a shortage of farm hands is prompting mechanization and it appears that credit is aiding and enabling this transition. The absence of a strong relationship with pumpsets could be on account of the variable representing irrigated land and perhaps government expenditure, which might include subsidies for pumpsets. There might thus be a conflation of the many explanatory variables.

It is apparent that availability of credit also reduces the labour intensity of agriculture by $2 \%$. However there is no evidence that could be is consistent with the idea of labour substituting mechanization. One possible interpretation is that increasingly some operations such as manual weeding are being replaced by the use of chemical weedicides and so on. Likewise greater ownership of tractors reflects this mechanization rather than just the paid out cost for machine use. Alternatively it could be that mechanization as represented by the responsiveness of tractors to credit flow substitutes animal power (rather than labour use).

Usually, this weak relationship especially of capital equipment such as tractor and pumpset is strongly suggestive that mechanization is preserving productivity or agricultural growth rather than enhancing it (Binswanger and Khandkher, 1992). In these contexts, credit can be interpreted as performing two roles the preservation of productivity levels by supporting mechanization of

\footnotetext{
${ }^{10}$ Recent years have seen a rapid growth in tractor financing by the manufacturers themselves. In the absence of data, this study only controls for it by using the number of input dealers, under a coarse assumption that this would be correlated with growth of tractor dealership.
} 
certain kinds and contributing to the growth of agricultural GDP through the purchase of variable inputs. All these results collectively suggest that credit indeed appears to have played a role in supporting the changing face of agriculture in India.

Overall, it seems quite clear that input use is sensitive to credit flow, whereas GDP of agriculture is not. This seems to indicate that the ability of credit to engineer growth in agricultural GDP is impeded by a problem of productivity and efficiency where the increase in input use and adjustments in the pattern of input use are not (yet) translating into higher agricultural GDP. Credit seems therefore to be an enabling input, but one whose effectiveness is undermined by low technical efficiency and productivity.

Table 3: Input Demand System : The Credit Elasticity of Input Demand from a SURE Model

\begin{tabular}{|l|c|c|c|}
\hline $\begin{array}{l}\text { Input or Agricultural } \\
\text { GSDP }\end{array}$ & $\begin{array}{c}\text { All } \\
\mathbf{( 1 9 9 5 / 9 6} \text { to 2011/12) }\end{array}$ & $\begin{array}{c}\text { Phase 1 } \\
\text { (1995/96 to 2003/04) } \\
\text { Phase I }\end{array}$ & $\begin{array}{c}\text { Phase 2 } \\
\text { (2004/05 to 2011/12) } \\
\text { Phase II }\end{array}$ \\
\hline Fertilizers & $0.17^{*}$ & $0.33^{* *}$ & 0.06 \\
\hline Chemicals & $0.51^{* * *}$ & 0.83 & 0.26 \\
\hline Tractors bought & $1.08^{* * *}$ & 0.10 & $1.67^{* * *}$ \\
\hline Pumpsets Energized & -0.84 & 0.04 & -0.83 \\
\hline $\begin{array}{l}\text { Labour hours per } \\
\text { hectare }\end{array}$ & $-0.20^{* *}$ & -0.28 & -0.16 \\
\hline $\begin{array}{l}\text { Animal hours per } \\
\text { hectare }\end{array}$ & 0.18 & -0.07 & -0.04 \\
\hline $\begin{array}{l}\text { Machine use (Rs. Per } \\
\text { hectare) }\end{array}$ & $-0.67^{* *}$ & -1.13 & -0.17 \\
\hline $\begin{array}{l}\text { Agricultural Gross State } \\
\text { Domestic product }\end{array}$ & 0.083 & -0.1 & 0.13 \\
\hline
\end{tabular}

NOTES:

(1) This is estimated as a SURE (Seemingly Unrelated Regression Equation). Breusch-Pagan test of independence: chi2(28) $=48.303, P r=0.0099$ suggests that the null hypothesis of independence is rejected and that these euqations need to be estimated as a system.

(2) The standard errors were bootstrapped with 200 repetitions to account for the inclusion of the predicted variable from the control function.

(3) The regression was run in deviation form to allow the direct use of SUREG command in STATA 13.

(4) The coefficient of the control function variable is not statistically significant in most versions of these regressions.

(5) The detailed regressions are available in Appendix 4 and 5 


\section{Concluding Remarks}

This paper sought to investigate the relationship between institutional credit to agriculture and agricultural Gross Domestic Product (GDP). Collectively, the results suggest that the fears that credit might be ineffective are perhaps misplaced. There is strong evidence that credit is indeed playing its part of supporting the purchase of inputs and perhaps even aiding the agricultural sector respond to its contextual constraints.

The evidence of the impact of credit on agricultural GDP is however weak at best , irrespective of the approach used, assuming a constant credit elasticity of agricultural GDP. Empirical patterns suggest that the relationship between credit and agricultural GDP is somewhat weak in the second phase. Further, as is evident from the regression of agricultural GDP on inputs and prices, other than fertilizers and labour, few inputs are strong drivers of GDP. In fact it appears that the sectoral composition and output prices are important determinants of agricultural GDP, apart from certain types of government expenditure and the irrigated area. Usually, this weak relationship especially of capital equipment such as tractor and pumpset is strongly suggestive that mechanization is preserving productivity or agricultural growth rather than enhancing it. In these contexts, credit can be interpreted as performing two roles the preservation of productivity levels by supporting mechanization of certain kinds and contributing to the growth of agricultural GDP

through the purchase of variable inputs. All these results collectively suggest that the success of credit in enabling the increase in use of purchased inputs and effecting changes in input mix, supporting the changing face of agriculture in India has not translated fully into agricultural GDP growth as such.

\section{REFERENCES}

Bhalla, G.S. andGurmail Singh (2010) Growth of Indian Agriculture: A District Level Study, Planning Commission, Government of India. Available at

http://planningcommission.nic.in/reports/sereport/ser/ser_gia2604.pdf

Binswanger, Hans.P. and Shahidur Khandker (1992): 'The Impact of Formal Finance on Rural Economy of India', World Bank, Working Paper No. 949. (also appeared in The Journal of Development Studies Volume 32, Issue 2, 1995)

Burgess, Robin and RohiniPande (2005) Do Rural Banks Matter? Evidence from the Indian Social Banking Experiment, American Economic Review, American Economic Association, vol. 95(3), pages 780-795, June.

Chaudhary, Shilpa (2013) Trends in Total Factor Productivity in Indian Agriculture: State-level Evidence using non-parametric Sequential Malmquist Index, Working Paper.

Chavan, P. (2009). How Rural is India's Agricultural Credit. The Hindu.

Cole, S. (2009). Fixing market failures or fixing elections? Agricultural credit in India.American Economic Journal: Applied Economics, 219-250. 
Das, Abhiman, Manjusha Senapati, Joice John (2009): 'Impact of Agricultural Credit on Agriculture Production: An Empirical Analysis in India', Reserve Bank of India Occasional Papers Vol. 30, No.2, Monsoon 2009

De, Sankarand and SiddharthVij (2012): Are Banks Responsive to Exogenous Shocks in Credit Demand? District - level Evidence from India, Research Paper, CAE, ISB, Hyderabad

Ghosh, Nilanjan (2010) Incredulity of Irresponsiveness: Is Agricultural Credit Productive? Commodity Vision, Volume 4, Issue 1, July 2010 Takshashila Academia of Economic Research Ltd, 2010

Golait, R. (2007): Current Issues in Agriculture Credit in India: An Assessment, RBI Occasional Papers, 28: 79-100.

Government of India (2013) Status of Indian Agriculture 2011-2012, Ministry of Agriculture, Government of India.

Imbens, Guido and Jeffrey Wooldridge (2007) Control Function and Related Methods, What's New in Econometrics? Lecture Notes 6, National Bureau of Economic Research (NBER), Summer 2007. http://www.nber.org/WNE/lect 6 controlfuncs.pdf. Accessed July, 2013.

Kanz, M. (2012). What does debt relief do for development? Evidence from India's bailout program for highly-indebted rural households. World Bank Policy Research Working Paper, 6258, Washington D.C.

Pavaskar Madhoo, Sarika Rachuri, Aditi Mehta (2011) Agricultural Credit Productivity in India Commodity Vision Volume 4, Issue 5, March 2011 Takshashila Academia of Economic Research Ltd, 2011

Preacher, K.J. and Hayes, A.F. (2008).Asymptotic and resampling strategies for assessing and comparing indirect effects in multiple mediator models.Behavioral Research Methods, 40, 879-891.

Rada, Nicholas E., 2013. Agricultural Growth in India: Examining the Post-Green Revolution Transition 2013 Annual Meeting, August 4-6, 2013, Washington, D.C. 149547, Agricultural and Applied Economics Association.

Ramakumar, R. and Chavan, P. (2007). Revival of agricultural credit in the 2000s: An Explanation. Economic and Political Weekly, 57-63.

Sriram, M.S.(2007): 'Productivity of Rural Credit: A Review of Issues and Some Recent Literature', Indian Institute of Management Ahmedabad, Working Paper No.2007-06-01.

Subbarao Duvvuri (2012) Agricultural Credit - Accomplishments and Challenges, Speech delivered at NABARD, July 12, 2012. 
APPENDIX 1 : Overview of GLC Flow during 2003-04 to 2013-14 - All India

\begin{tabular}{|c|c|c|c|}
\hline Year & $\begin{array}{l}\text { No of agriculture } \\
\text { accounts(in`lakh) }\end{array}$ & $\begin{array}{l}\text { Amount } \\
\text { disbursed(in } \\
\text { crore) }\end{array}$ & $\begin{array}{l}\text { Per } \\
\text { account } \\
\text { (in ) }\end{array}$ \\
\hline $2003-2004$ & NA & 86981 & \\
\hline $2004-2005$ & NA & 125309 & \\
\hline $2005-2006$ & NA & 180486 & \\
\hline 2006-07 & 423.13 & 229400 & 54215 \\
\hline 2007-08 & 439.34 & 254658 & 57964 \\
\hline 2008-09 & 456.1 & 301908 & 66193 \\
\hline 2009-10 & 482.3 & 384514 & 79725 \\
\hline $2010-11$ & 549.6 & 468291 & 85206 \\
\hline $2011-12(\mathrm{P})$ & 646.57 & 511029 & 79037 \\
\hline $2012-13(\mathrm{P})$ & 703.57 & 607375 & 86328 \\
\hline $2013-14$ & 799.68 & 711621 & 88988 \\
\hline \multicolumn{4}{|l|}{$\%$ growth in $2013-14$ over } \\
\hline $2012-13$ & 13.66 & 17.16 & 3.08 \\
\hline CAGR(2003-04 to 2013-14) & $9.52^{*}$ & 23.39 & $7.34^{*}$ \\
\hline \multicolumn{4}{|l|}{ CAGR(2004-05 to 2006-07) } \\
\hline (Doubling period) & & 35.30 & \\
\hline \multicolumn{4}{|l|}{ CAGR(2007-08 to $2013-14)$} \\
\hline (Post doubling period) & 10.50 & 18.68 & 7.41 \\
\hline
\end{tabular}

Note: * denotes that CAGR is for the period 2006-07 to 2013-14

Source: IBA for Commercial Banks and NABARD for Cooperative Banks and RRBs 


\section{APPENDIX 2: Empirical Strategy: The Methods Described}

\section{Method 1: Time Series Simple Model}

The first method is a simple model, where agricultural GDP is regressed on the current time period's credit to agriculture. This model is estimated as a panel model with fixed effects, based on Hausman test for choice of models. This model is also run separately for the first phase (1995-96 to 2003-04) and second phase (2004-05 to 2010-11) and for individual states.

$G D P_{i t}=\alpha-\rho \ln \left(K_{i t-1}\right)+e_{i t}$

Where $i$ refers to the state and $t$ the financial year.

$\rho$ is the 'lagged' credit elasticity of agricultural GDP. In this version, the non-lagged version is presented but the results are comparable.

\section{Method 2: Reduced Form Control Function Approach}

\section{Credit equation/ Control Function}

The first step in this method is to address the endogeneity of credit. Since the demand for credit itself could be a result of agricultural GDP, a control function approach is adopted to separate out that part of credit that could be due to exogenous factors and that part which might represent the endogenous component. In this regression, we use variables that are hypothesized to exogenously influence the level of credit. This includes the previous year's rainfall, per capita income, structure of agriculture and the number of branches of commercial banks in the state.

$\ln \left(K_{i t}\right)=a+\sum a_{i} \ln \left(E_{i t}\right)+\theta$

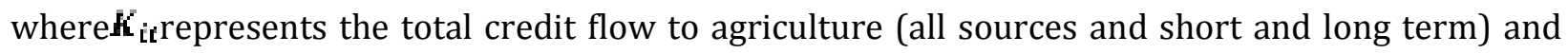
Ett. 1 can be regarded as the endogenous part of credit, the estimated values of which are used in the next stage regression.

\section{Outcome function}

The outcome function is essentially a hybrid production-profit function that maps a set of inputs to outputs, controlling for exogenous factors such as the weather, market prices of output and inputs, public infrastructure. Since the aggregate value of output is likely sensitive to the composition of crops or the cropping pattern, the regression will control for the proportion of area under the major groups of crops - foodgrains (cereals and pulses), oilseeds, fibre, horticulture, spices and plantation crops (such as tea, rubber and coffee). In lieu of private and public capital stock and investment in agriculture which capture capital inputs into production but are not available for all the states, select machinery and equipment are included. A key component of this regression is the estimated "control" variable from the Control Function described above that serves to control for endogeneity and thereby allow us to interpret the coefficient on credit as a causal effect rather than mere correlation. 
$\ln (G D P)=\alpha+\rho \ln \left(K_{i t}\right)+\delta \ln \left(b_{i t}\right)-\sum_{k} \beta_{k} \ln \left(Z_{i k t}\right)+\sum_{k} \gamma_{h} P_{i h t}-\sum_{l} 0_{1} \theta_{i l t}+\varepsilon_{i t}$

where $\mathrm{K}$ is the credit flow, $\mathrm{Z}$ is the vector of inputs (including $\mathrm{N}, \mathrm{P}$ K fertilizers, pesticides, tractors and pumpsets) and other factors ( 0 ) such as rainfall, per capita state domestic product, percentage of villages in the state that are electrified and so on, $\mathrm{P}$ is the vector of prices, etc.

$\rho$ is the credit elasticity of agricultural GDP, with associated bootstrapped standard errors for hypothesis testing.

\section{Method 3: Reduced Form Control Function Approach}

\section{(a) Credit equation/ Control Function}

$\ln \left(K_{\text {it }}\right)=a+\sum a_{i} \ln \left(E_{i t}\right)+\theta$

\section{(b) Input / Capital Demand Equations}

In order to retrieve the coefficients that represent the different pathways, we will estimate the set of structural equations to understand the relative contribution of credit to different components of the agricultural production-profit function.

$\ln \left(Z_{i k t}\right)=\alpha-\pi_{k} \ln \left(K_{i t}\right)+\delta \ln \left(\delta_{i t}\right)+\sum \gamma_{h}{ }_{h} P_{i h t}-\sum 9_{l}^{\prime} \theta_{i t t}+\varepsilon_{i t}$

The input demand functions depend on credit (among other things). We then estimate input demand equations as a system, where the inputs are measured in physical units, and explanatory variables include both the "control" variable and credit. The rapid changes in the cropping pattern in India in the past two decades is both in response to the growing market opportunities as well as the growth of processing sectors which in turn are likely impacted by indirect credit. So the composition of the agricultural sector and the growing importance of livestock, poultry and fisheries would need to be accounted for. Credit for purchase of milch animals as well as construction of broiler sheds for contract growing are important components of agricultural output. Due to paucity of detailed annual data on draught animals, share of livestock output in total agricultural output is used as a proxy. The inputs used include fertilizers such as Nitrogen $(\mathrm{N})$, Phosphorous (P) and Potassium (K), pesticides. Standard errors are computed through bootstrapping procedures to account for the fact that these regressions use predicted values at different stages. 


\section{(c) Outcome function}

$\ln \left(G D P_{i t}\right)=\alpha+\rho \ln \left(\boldsymbol{K}_{i t}\right)+\delta \ln \left(\hat{g}_{i t}\right)+\sum_{k} \beta_{k} \ln \left(Z_{i k t}\right)+\sum_{i t} \gamma_{h} \boldsymbol{P}_{i h t}+\sum_{i} \oint_{l} \theta_{i t t}+\varepsilon_{i t}$

We then estimate the function explaining agricultural GDP in monetary terms as a hybrid profit function. Compute the total impact of credit as the sum of the impacts on inputs weighted by the impact of the input in question on agricultural GDP.

\section{(d) Credit Elasticity of Agricultural GDP}

Etastictty $=\rho-\sum_{k} \pi_{k} \beta_{i k}$

The impact of credit on agricultural GDP can then be derived as the sum of the contribution of credit to the use of specific inputs, capital or the cropping pattern, weighted by the contribution of these to the total value of agricultural production. Standard errors reflect bootstrapped estimates. 
APPENDIX 3: Data and Sources

\begin{tabular}{|c|c|c|c|c|c|}
\hline Variable name & Variable label (units) & Mean & Min & Max & Source \\
\hline agelectariff & $\begin{array}{l}\text { Power tariff to agriculture } \\
\text { (paise } / \mathrm{kWh} \text { ) }\end{array}$ & 80.72 & 0 & 512.88 & $\begin{array}{l}\text { Central Electricity Authority } \\
\text { EPWRF time series }\end{array}$ \\
\hline animalhoursha & Animal (hours/ha) & 57.42 & 1.15 & 241.16 & $\begin{array}{l}\text { Ministry of Agriculture, Cost of } \\
\text { Cultivation Studies }\end{array}$ \\
\hline $\begin{array}{l}\text { areanonfoodtot } \\
\text { al }\end{array}$ & $\begin{array}{l}\text { Total area unde nonfood crops } \\
\text { (000 hectares) }\end{array}$ & 2905.47 & 1 & 52398.00 & Ministry of Agriculture \\
\hline cagalliedtotal & $\begin{array}{l}\text { Total capital expenditure on } \\
\text { agriculture and allied services. }\end{array}$ & 13384.02 & $\begin{array}{l}- \\
67499 \\
\end{array}$ & 541032.00 & $\begin{array}{l}\text { State Finances : A Study of } \\
\text { Budgets, RBI }\end{array}$ \\
\hline $\begin{array}{l}\text { cladvecoservtot } \\
\text { al }\end{array}$ & $\begin{array}{l}\text { Total capital expenditure on } \\
\text { economic services. }\end{array}$ & 64155.42 & $\begin{array}{l}- \\
18091\end{array}$ & 1881901.00 & $\begin{array}{l}\text { State Finances : A Study of } \\
\text { Budgets, RBI }\end{array}$ \\
\hline commercial & $\begin{array}{l}\text { Number of commercial bank } \\
\text { branches }\end{array}$ & 4165.49 & 7 & 101261.00 & CMIE \\
\hline egg_prod & Production(in Lakhs) & 12404.66 & 1 & 321068.00 & $\begin{array}{l}\text { Ministry of Agriculture, } \\
\text { Agricultural Statistics at a } \\
\text { Glance }\end{array}$ \\
\hline $\begin{array}{l}\text { fert_salepoint_t } \\
\text { otal }\end{array}$ & $\begin{array}{l}\text { No. of Fertilizer Sale Points } \\
\text { (Total) }\end{array}$ & 7835.36 & 0 & 72344.00 & $\begin{array}{l}\text { Ministry of Agriculture, Cost of } \\
\text { Cultivation Studies }\end{array}$ \\
\hline gca & Gross Cropped Area ('000 ha) & 11606.41 & 2 & 195357.00 & Ministry of Agriculture \\
\hline gsdp_agri & GSDP(in Rs. Lakh) & 2943807.00 & 3943 & 127000000.00 & Ministry of Agriculture \\
\hline irrcanal & Canal Irrigated area ( $000 \mathrm{ha}$ ) & 2178.10 & 0 & 17995.00 & Ministry of Agriculture \\
\hline irrtank & Tank Irrigated area ( $000 \mathrm{ha}$ ) & 312.70 & 0 & 3343.00 & Ministry of Agriculture \\
\hline $\mathrm{k}$ & Potassic fertilizers ('000 tonnes) & 175.45 & 0.02 & 3632.40 & Fertiliser Association of India \\
\hline labhoursha & Labour (hours/ha) wtd avg & 568.69 & $\begin{array}{l}211.6 \\
6\end{array}$ & 1691.17 & $\begin{array}{l}\text { Ministry of Agriculture, Cost of } \\
\text { Cultivation Studies }\end{array}$ \\
\hline machinersperha & Machine (Rs./ha) & 1417.22 & 0 & 6028.95 & $\begin{array}{l}\text { Ministry of Agriculture, Cost of } \\
\text { Cultivation Studies }\end{array}$ \\
\hline milk_prod & Production(in '000 MT) & 2766.42 & 1 & 21031.00 & $\begin{array}{l}\text { Ministry of Agriculture, } \\
\text { Agricultural Statistics at a } \\
\text { Glance }\end{array}$ \\
\hline $\mathrm{n}$ & $\begin{array}{l}\text { Nitrogenous fertilizers ('000 } \\
\text { tonnes) }\end{array}$ & 1092.02 & 0.6 & 17300.25 & Fertiliser Association of India \\
\hline nsa & Net Sown Area ('000 ha) & 8631.22 & 1 & 142960.00 & Ministry of Agriculture \\
\hline $\begin{array}{l}\text { output_byprodu } \\
\text { ct }\end{array}$ & $\begin{array}{l}\text { byproduct: Value of Output(Rs. } \\
\text { Lakhs) }\end{array}$ & 176028.30 & 0 & 3222156.00 & National Accounts Statistics \\
\hline output_cereals & $\begin{array}{l}\text { Cereals: Value of Output(Rs. } \\
\text { Lakhs) }\end{array}$ & 810692.80 & 0 & 16300000.00 & National Accounts Statistics \\
\hline output_drugs & drugs: Value of Output(Rs. Lakhs) & 81793.53 & 0 & 1434137.00 & National Accounts Statistics \\
\hline output_fibres & fibres: Value of Output(Rs. Lakhs) & 94783.26 & 0 & 2756026.00 & National Accounts Statistics \\
\hline output_fish & fish: Value of Output(Rs. Lakhs) & 183344.90 & 19 & 3906563.00 & National Accounts Statistics \\
\hline output_fruits & fruits: Value of Output(Rs. Lakhs) & 607584.60 & 0 & 13800000.00 & National Accounts Statistics \\
\hline
\end{tabular}




\begin{tabular}{|c|c|c|c|c|c|}
\hline Variable name & Variable label (units) & Mean & Min & Max & Source \\
\hline output_livestock & $\begin{array}{l}\text { livestock: Value of Output(Rs. } \\
\text { Lakhs) }\end{array}$ & 924819.20 & 479 & 21200000.00 & National Accounts Statistics \\
\hline output_oilseeds & $\begin{array}{l}\text { oilseeds: Value of Output(Rs. } \\
\text { Lakhs) }\end{array}$ & 257429.60 & 0 & 5449477.00 & National Accounts Statistics \\
\hline $\begin{array}{l}\text { output_othercro } \\
\text { ps }\end{array}$ & $\begin{array}{l}\text { othercrops: Value of Output(Rs. } \\
\text { Lakhs) }\end{array}$ & 140840.20 & 0 & 3097888.00 & National Accounts Statistics \\
\hline output_pulses & Pulses: Value of Output(Rs. Lakhs) & 115964.70 & 0 & 2315486.00 & National Accounts Statistics \\
\hline output_spices & spices: Value of Output(Rs. Lakhs) & 79445.64 & 0 & 1838363.00 & National Accounts Statistics \\
\hline output_sugar & sugar: Value of Output(Rs. Lakhs) & 206510.30 & 0 & 3665781.00 & National Accounts Statistics \\
\hline $\mathrm{p}$ & $\begin{array}{l}\text { Phosphatic fertilizers ('000 } \\
\text { tonnes) }\end{array}$ & 429.72 & 0.38 & 8049.70 & Fertiliser Association of India \\
\hline pcsdpcurrent & Per capita State Domestic Product & 144345.00 & 3037 & 47200000.00 & National Accounts Statistics \\
\hline $\begin{array}{l}\text { pcvillageselectri } \\
\text { c }\end{array}$ & Percentage of villages electrified & 85.16 & 0 & 285.87 & $\begin{array}{l}\text { Central Electricity Authority } \\
\text { EPWRF time series }\end{array}$ \\
\hline pesticide & $\begin{array}{l}\text { Pesticide Technical Grade } \\
\text { Consumption (MT) }\end{array}$ & 2998.05 & 0.39 & 63651.00 & Fertiliser Association of India \\
\hline pfertpest & $\begin{array}{l}\text { Price Index for Fertilisers and } \\
\text { Pesticides }\end{array}$ & 100.50 & 70.42 & 148.50 & RBI \\
\hline pfodder & Price Index for Fodder & 114.77 & 63.17 & 245.64 & RBI \\
\hline pfoodarticles & Price Index for Food Articles & 121.15 & 67.9 & 215.20 & RBI \\
\hline pfuelpower & Price Index for Fuel and Power & 120.95 & 66.1 & 195.53 & RBI \\
\hline ptractor & Price Index for Tractors & 101.75 & 65.54 & 144.21 & RBI \\
\hline pumpset & Pumpsets energized & 835496.10 & 0 & 16300000.00 & Central Electiricty Authority \\
\hline ragrialliedtotal & $\begin{array}{l}\text { Government revenue expenditure } \\
\text { on agriculture and allied activities }\end{array}$ & 132352.00 & 415 & 4339185.00 & $\begin{array}{l}\text { State Finances : A Study of } \\
\text { Budgets, RBI }\end{array}$ \\
\hline rainavgann & Rainfall Annual (mm) & 995.41 & 0 & 2630.00 & Ministry of Agriculture \\
\hline seeds & $\begin{array}{l}\text { Certified seeds distributed (lakh } \\
\text { quintals) }\end{array}$ & 132.78 & 62.2 & 283.85 & Fertiliser Association of India \\
\hline total & Total Disbursment (in Rs. lakh) & 824263.20 & 0 & 46700000.00 & DEAR, NABARD \\
\hline tractorsale & Sale of Tractors & 28179.76 & 36 & 545109.00 & $\begin{array}{l}\text { Agricultural research data } \\
\text { book IASRI }\end{array}$ \\
\hline tractorstock & Stock of Tractors & 312343.40 & 4629 & 4547080.00 & CMIE \\
\hline $\begin{array}{l}\text { unskilledlabour } \\
\text { ers }\end{array}$ & $\begin{array}{l}\text { Wage Index for unskilled } \\
\text { labourers }\end{array}$ & 85.46 & 32.33 & 393.82 & RBI \\
\hline villelectric & Percentage of villages electrified & 85.16 & 0 & 285.87 & EPWRF time series \\
\hline wpi_all_avg & $\begin{array}{l}\text { Wholesale Price Index (Financial } \\
\text { Year averages) }\end{array}$ & 102.51 & 63.58 & 152.33 & RBI \\
\hline wpi_allcalavg & $\begin{array}{l}\text { Wholesale Price Index (Calendar } \\
\text { Year averages) }\end{array}$ & 97.05 & 58.28 & 164.93 & RBI \\
\hline
\end{tabular}

Observations with missing values are excluded from the regression 
APPENDIX 4 : Regression Results for SURE Model 3.

\begin{tabular}{|c|c|c|c|c|c|c|}
\hline \multirow[t]{2}{*}{ Variables (in deviation, log form) } & \multicolumn{3}{|l|}{ Fertilizers } & \multicolumn{3}{|c|}{ Pesticides } \\
\hline & $\begin{array}{l}\text { Both } \\
\text { Phases } \\
\text { b/t }\end{array}$ & $\begin{array}{l}\text { Phase } 1 \\
\text { b/t }\end{array}$ & $\begin{array}{l}\text { Phase } 2 \\
\text { b/t }\end{array}$ & $\begin{array}{l}\text { Both } \\
\text { Phases } \\
\text { b/t }\end{array}$ & $\begin{array}{l}\text { Phase } 1 \\
\text { b/t }\end{array}$ & $\begin{array}{l}\text { Phase } 2 \\
\text { b/t }\end{array}$ \\
\hline Credit & $\begin{array}{l}0.169 \\
(1.88)\end{array}$ & $\begin{array}{l}0.326^{*} \\
(2.03)\end{array}$ & $\begin{array}{l}0.058 \\
(0.51)\end{array}$ & $\begin{array}{l}0.510^{* *} \\
(2.69)\end{array}$ & $\begin{array}{l}0.827 \\
(1.54)\end{array}$ & $\begin{array}{l}0.263 \\
(1.30)\end{array}$ \\
\hline "Error" from Control function & $\begin{array}{l}0.003 \\
(0.05)\end{array}$ & $\begin{array}{l}0.025 \\
(0.11)\end{array}$ & $\begin{array}{l}-0.103 \\
(-0.86)\end{array}$ & $\begin{array}{l}0.077 \\
(0.46)\end{array}$ & $\begin{array}{l}-0.035 \\
(-0.05)\end{array}$ & $\begin{array}{l}0.530 \\
(1.58)\end{array}$ \\
\hline Net Sown Area & $\begin{array}{l}0.632^{*} \\
(2.01)\end{array}$ & $\begin{array}{l}0.441 \\
(0.88)\end{array}$ & $\begin{array}{l}0.255 \\
(0.50)\end{array}$ & $\begin{array}{l}1.261 \\
(1.39)\end{array}$ & $\begin{array}{l}0.762 \\
(0.57)\end{array}$ & $\begin{array}{l}0.288 \\
(0.22)\end{array}$ \\
\hline Area under non-food Crops & $\begin{array}{l}0.000 \\
(1.04)\end{array}$ & $\begin{array}{l}0.000 \\
(0.25)\end{array}$ & $\begin{array}{l}0.000 \\
(1.24)\end{array}$ & $\begin{array}{l}-0.000 \\
(-0.36)\end{array}$ & $\begin{array}{l}0.000 \\
(1.51)\end{array}$ & $\begin{array}{l}-0.000 \\
(-1.50)\end{array}$ \\
\hline Fertilizer Sale points & $\begin{array}{l}0.000 \\
(0.73)\end{array}$ & $\begin{array}{l}0.000 \\
(1.30)\end{array}$ & $\begin{array}{l}0.000 \\
(0.27)\end{array}$ & $\begin{array}{l}0.000 \\
(0.15)\end{array}$ & $\begin{array}{l}0.000 \\
(0.93)\end{array}$ & $\begin{array}{l}-0.000 \\
(-0.50)\end{array}$ \\
\hline Index of Fertilizer/Pesticide prices & $\begin{array}{l}-0.002 \\
(-0.58)\end{array}$ & $\begin{array}{l}0.036^{*} \\
(1.96)\end{array}$ & $\begin{array}{l}0.021 \\
(1.14)\end{array}$ & $\begin{array}{l}-0.011 \\
(-0.80)\end{array}$ & $\begin{array}{l}-0.006 \\
(-0.09)\end{array}$ & $\begin{array}{l}-0.069 \\
(-1.47)\end{array}$ \\
\hline Wholesale Price Index & $\begin{array}{l}-0.002 \\
(-0.46)\end{array}$ & $\begin{array}{l}0.015 \\
(0.92)\end{array}$ & $\begin{array}{l}0.002 \\
(0.15)\end{array}$ & $\begin{array}{l}-0.026^{*} \\
(-2.00)\end{array}$ & $\begin{array}{l}-0.079 \\
(-1.17)\end{array}$ & $\begin{array}{l}-0.008 \\
(-0.28)\end{array}$ \\
\hline Lagged Food Articles Price Index & $\begin{array}{l}0.006^{* *} \\
(2.74)\end{array}$ & $\begin{array}{l}-0.074 \\
(-1.83)\end{array}$ & $\begin{array}{l}-0.001 \\
(-0.13)\end{array}$ & $\begin{array}{l}0.016^{*} \\
(2.32)\end{array}$ & $\begin{array}{l}0.068 \\
(0.45)\end{array}$ & $\begin{array}{l}0.018 \\
(0.80)\end{array}$ \\
\hline \multicolumn{7}{|c|}{ (LAGGED) SHARE OF TOTAL VALUE OF AGRICULTURAL OUTPUT } \\
\hline Fibres & $\begin{array}{l}0.003^{* * *} \\
(3.71)\end{array}$ & $\begin{array}{l}0.002 \\
(1.52)\end{array}$ & $\begin{array}{l}0.002 * \\
(2.06)\end{array}$ & $\begin{array}{l}-0.002 \\
(-0.73)\end{array}$ & $\begin{array}{l}-0.002 \\
(-0.36)\end{array}$ & $\begin{array}{l}-0.002 \\
(-0.66)\end{array}$ \\
\hline Spices & $\begin{array}{l}-0.000 \\
(-0.09)\end{array}$ & $\begin{array}{l}-0.001 \\
(-0.53)\end{array}$ & $\begin{array}{l}0.000 \\
(0.23)\end{array}$ & $\begin{array}{l}0.001 \\
(0.21)\end{array}$ & $\begin{array}{l}0.008 \\
(0.75)\end{array}$ & $\begin{array}{l}-0.004 \\
(-0.69)\end{array}$ \\
\hline Cereals & $\begin{array}{l}0.000 \\
(0.69)\end{array}$ & $\begin{array}{l}0.001 \\
(1.06)\end{array}$ & $\begin{array}{l}-0.000 \\
(-0.27)\end{array}$ & $\begin{array}{l}-0.001 \\
(-0.67)\end{array}$ & $\begin{array}{l}-0.002 \\
(-0.64)\end{array}$ & $\begin{array}{l}0.001 \\
(0.47)\end{array}$ \\
\hline Fruits & $\begin{array}{l}-0.000 \\
(-0.04)\end{array}$ & $\begin{array}{l}-0.000 \\
(-0.28)\end{array}$ & $\begin{array}{l}0.000 \\
(0.12)\end{array}$ & $\begin{array}{l}0.000 \\
(0.03)\end{array}$ & $\begin{array}{l}-0.001 \\
(-0.34)\end{array}$ & $\begin{array}{l}0.000 \\
(0.14)\end{array}$ \\
\hline Oilseeds & $\begin{array}{l}0.000 \\
(0.53)\end{array}$ & $\begin{array}{l}-0.000 \\
(-0.23)\end{array}$ & $\begin{array}{l}0.000 \\
(0.49)\end{array}$ & $\begin{array}{l}0.001 \\
(0.42)\end{array}$ & $\begin{array}{l}0.003 \\
(0.58)\end{array}$ & $\begin{array}{l}-0.004 \\
(-1.21)\end{array}$ \\
\hline Pulses & $\begin{array}{l}0.001 \\
(0.72)\end{array}$ & $\begin{array}{l}-0.000 \\
(-0.03)\end{array}$ & $\begin{array}{l}0.000 \\
(0.06)\end{array}$ & $\begin{array}{l}-0.000 \\
(-0.17)\end{array}$ & $\begin{array}{l}-0.001 \\
(-0.27)\end{array}$ & $\begin{array}{l}-0.007 \\
(-1.28)\end{array}$ \\
\hline Sugar & $\begin{array}{l}-0.000 \\
(-0.37) \\
\end{array}$ & $\begin{array}{l}0.000 \\
(0.03)\end{array}$ & $\begin{array}{l}-0.000 \\
(-0.01)\end{array}$ & $\begin{array}{l}-0.001 \\
(-0.53) \\
\end{array}$ & $\begin{array}{l}0.001 \\
(0.25)\end{array}$ & $\begin{array}{l}-0.001 \\
(-0.21)\end{array}$ \\
\hline Per Capita State Domestic Product & $\begin{array}{l}-0.000 \\
(-0.32)\end{array}$ & $\begin{array}{l}-0.000 \\
(-0.46)\end{array}$ & $\begin{array}{l}0.000 \\
(0.36)\end{array}$ & $\begin{array}{l}-0.000 \\
(-0.07)\end{array}$ & $\begin{array}{l}0.000 \\
(0.19)\end{array}$ & $\begin{array}{l}-0.000 \\
(-0.39)\end{array}$ \\
\hline Annual Average Rainfall & $\begin{array}{l}0.016 \\
(0.36)\end{array}$ & $\begin{array}{l}0.024 \\
(0.26)\end{array}$ & $\begin{array}{l}0.004 \\
(0.06)\end{array}$ & $\begin{array}{l}-0.165 \\
(-1.09)\end{array}$ & $\begin{array}{l}-0.041 \\
(-0.09)\end{array}$ & $\begin{array}{l}0.078 \\
(0.32)\end{array}$ \\
\hline Constant & $\begin{array}{l}-0.182 \\
(-0.49)\end{array}$ & $\begin{array}{l}2.855 \\
(1.92)\end{array}$ & $\begin{array}{l}-2.394 \\
(-1.38)\end{array}$ & $\begin{array}{l}2.154^{*} \\
(1.98)\end{array}$ & $\begin{array}{l}1.419 \\
(0.27)\end{array}$ & $\begin{array}{l}6.199 \\
(1.60)\end{array}$ \\
\hline
\end{tabular}

b refers to coefficient and t refers to $t$ value (in parenthesis) 
APPENDIX 4 (Continued)

\begin{tabular}{|c|c|c|c|c|c|c|c|}
\hline \multirow[t]{2}{*}{ Variables (in deviation, log form) } & \multicolumn{3}{|c|}{ Animal hours per ha } & \multicolumn{3}{|c|}{ Machine expenses per hectare } & \multirow{2}{*}{$\begin{array}{l}\text { Labour hou } \\
\text { Both } \\
\text { Phases } \\
\text { b/t } \\
\end{array}$} \\
\hline & $\begin{array}{l}\text { Both } \\
\text { Phases } \\
\text { b/t }\end{array}$ & $\begin{array}{l}\text { Phase } 1 \\
\text { b/t }\end{array}$ & $\begin{array}{l}\text { Phase } 2 \\
\text { b/t }\end{array}$ & $\begin{array}{l}\text { Both } \\
\text { Phases } \\
\text { b/t }\end{array}$ & $\begin{array}{l}\text { Phase } 1 \\
\text { b/t }\end{array}$ & $\begin{array}{l}\text { Phase } 2 \\
\text { b/t }\end{array}$ & \\
\hline Credit & $\begin{array}{l}0.176 \\
(0.83)\end{array}$ & $\begin{array}{l}-0.070 \\
(-0.21)\end{array}$ & $\begin{array}{l}-0.038 \\
(-0.09)\end{array}$ & $\begin{array}{l}-0.671^{*} \\
(-2.02)\end{array}$ & $\begin{array}{l}-1.125 \\
(-1.34)\end{array}$ & $\begin{array}{l}-0.172 \\
(-0.77)\end{array}$ & $\begin{array}{l}-0.200^{*} \\
(-2.36)\end{array}$ \\
\hline "Error" from Control function & $\begin{array}{l}0.147 \\
(0.62)\end{array}$ & $\begin{array}{l}0.090 \\
(0.19)\end{array}$ & $\begin{array}{l}0.231 \\
(0.46)\end{array}$ & $\begin{array}{l}-0.633 \\
(-0.94)\end{array}$ & $\begin{array}{l}-0.062 \\
(-0.05)\end{array}$ & $\begin{array}{l}-0.297 \\
(-1.09)\end{array}$ & $\begin{array}{l}-0.078 \\
(-1.01)\end{array}$ \\
\hline Net Sown Area & $\begin{array}{l}0.865 \\
(1.46)\end{array}$ & $\begin{array}{l}0.249 \\
(0.26)\end{array}$ & $\begin{array}{l}2.563 \\
(1.45)\end{array}$ & $\begin{array}{l}0.679 \\
(0.72)\end{array}$ & $\begin{array}{l}2.608 \\
(1.06)\end{array}$ & $\begin{array}{l}-0.259 \\
(-0.22)\end{array}$ & $\begin{array}{l}0.252 \\
(1.15)\end{array}$ \\
\hline Area under non-food Crops & $\begin{array}{l}0.000 \\
(0.82)\end{array}$ & $\begin{array}{l}-0.000 \\
(-0.68)\end{array}$ & $\begin{array}{l}0.000 \\
(0.31)\end{array}$ & $\begin{array}{l}-0.000 \\
(-0.05)\end{array}$ & $\begin{array}{l}0.000 \\
(0.47)\end{array}$ & $\begin{array}{l}-0.000 \\
(-0.43)\end{array}$ & $\begin{array}{l}0.000 \\
(0.54)\end{array}$ \\
\hline Fertilizer Sale points & $\begin{array}{l}0.000 \\
(0.68)\end{array}$ & $\begin{array}{l}0.000 \\
(0.64)\end{array}$ & $\begin{array}{l}0.000 \\
(0.34)\end{array}$ & $\begin{array}{l}-0.000 \\
(-0.65)\end{array}$ & $\begin{array}{l}-0.000 \\
(-1.40)\end{array}$ & $\begin{array}{l}0.000 \\
(0.59)\end{array}$ & $\begin{array}{l}-0.000 \\
(-1.67)\end{array}$ \\
\hline Index of Fertilizer/Pesticide prices & $\begin{array}{l}-0.020 \\
(-1.19)\end{array}$ & $\begin{array}{l}-0.041 \\
(-0.79)\end{array}$ & $\begin{array}{l}0.048 \\
(0.58)\end{array}$ & $\begin{array}{l}0.032 \\
(1.82)\end{array}$ & $\begin{array}{l}0.021 \\
(0.20)\end{array}$ & $\begin{array}{l}0.030 \\
(0.74)\end{array}$ & $\begin{array}{l}-0.007 \\
(-1.44)\end{array}$ \\
\hline Wholesale Price Index & $\begin{array}{l}0.007 \\
(0.52)\end{array}$ & $\begin{array}{l}-0.020 \\
(-0.55)\end{array}$ & $\begin{array}{l}0.045 \\
(0.97)\end{array}$ & $\begin{array}{l}0.056^{*} \\
(2.43)\end{array}$ & $\begin{array}{l}0.072 \\
(0.76)\end{array}$ & $\begin{array}{l}-0.005 \\
(-0.25)\end{array}$ & $\begin{array}{l}0.011^{*} \\
(2.03)\end{array}$ \\
\hline Lagged Food Articles Price Index & $\begin{array}{l}-0.007 \\
(-0.93)\end{array}$ & $\begin{array}{l}0.053 \\
(0.51)\end{array}$ & $\begin{array}{l}-0.036 \\
(-1.12)\end{array}$ & $\begin{array}{l}-0.030^{* *} \\
(-2.96)\end{array}$ & $\begin{array}{l}0.015 \\
(0.07)\end{array}$ & $\begin{array}{l}0.004 \\
(0.28)\end{array}$ & $\begin{array}{l}-0.001 \\
(-0.30)\end{array}$ \\
\hline (LAGGED) SHARE OF TOTAL VALU & TRICULT & OUTPUT & & & & & \\
\hline Fibres & $\begin{array}{l}0.001 \\
(0.43)\end{array}$ & $\begin{array}{l}-0.003 \\
(-0.75)\end{array}$ & $\begin{array}{l}0.000 \\
(0.01)\end{array}$ & $\begin{array}{l}-0.003 \\
(-1.34)\end{array}$ & $\begin{array}{l}-0.004 \\
(-0.47)\end{array}$ & $\begin{array}{l}0.001 \\
(0.38)\end{array}$ & $\begin{array}{l}0.002^{*} \\
(2.17)\end{array}$ \\
\hline Spices & $\begin{array}{l}0.001 \\
(0.23)\end{array}$ & $\begin{array}{l}-0.006 \\
(-1.05)\end{array}$ & $\begin{array}{l}0.007 \\
(0.63)\end{array}$ & $\begin{array}{l}-0.013 \\
(-1.31)\end{array}$ & $\begin{array}{l}-0.028 \\
(-1.20)\end{array}$ & $\begin{array}{l}-0.002 \\
(-0.47)\end{array}$ & $\begin{array}{l}-0.002 \\
(-1.27)\end{array}$ \\
\hline Cereals & $\begin{array}{l}0.003^{*} \\
(2.46)\end{array}$ & $\begin{array}{l}0.002 \\
(1.01)\end{array}$ & $\begin{array}{l}0.006 \\
(1.85)\end{array}$ & $\begin{array}{l}0.002 \\
(1.24)\end{array}$ & $\begin{array}{l}0.008 \\
(1.77)\end{array}$ & $\begin{array}{l}-0.002 \\
(-1.25)\end{array}$ & $\begin{array}{l}0.001^{*} \\
(2.19)\end{array}$ \\
\hline Fruits & $\begin{array}{l}0.002 \\
(1.31)\end{array}$ & $\begin{array}{l}0.001 \\
(0.45)\end{array}$ & $\begin{array}{l}0.004 \\
(0.98)\end{array}$ & $\begin{array}{l}-0.002 \\
(-0.88)\end{array}$ & $\begin{array}{l}0.001 \\
(0.29)\end{array}$ & $\begin{array}{l}-0.003 \\
(-1.12)\end{array}$ & $\begin{array}{l}0.001 \\
(1.15)\end{array}$ \\
\hline Oilseeds & $\begin{array}{l}-0.000 \\
(-0.08)\end{array}$ & $\begin{array}{l}0.002 \\
(0.75)\end{array}$ & $\begin{array}{l}-0.004 \\
(-0.80)\end{array}$ & $\begin{array}{l}0.001 \\
(0.54)\end{array}$ & $\begin{array}{l}-0.000 \\
(-0.01)\end{array}$ & $\begin{array}{l}0.002 \\
(0.75)\end{array}$ & $\begin{array}{l}0.001 \\
(0.85)\end{array}$ \\
\hline Pulses & $\begin{array}{l}-0.004 \\
(-1.26)\end{array}$ & $\begin{array}{l}-0.002 \\
(-0.50)\end{array}$ & $\begin{array}{l}-0.009 \\
(-1.15)\end{array}$ & $\begin{array}{l}0.006 \\
(1.79)\end{array}$ & $\begin{array}{l}0.009 \\
(1.12)\end{array}$ & $\begin{array}{l}0.003 \\
(0.69)\end{array}$ & $\begin{array}{l}-0.003^{* * *} \\
(-3.41)\end{array}$ \\
\hline Sugar & $\begin{array}{l}0.003 \\
(1.09)\end{array}$ & $\begin{array}{l}-0.000 \\
(-0.02)\end{array}$ & $\begin{array}{l}0.009 \\
(1.81)\end{array}$ & $\begin{array}{l}0.000 \\
(0.15)\end{array}$ & $\begin{array}{l}-0.004 \\
(-0.41)\end{array}$ & $\begin{array}{l}-0.002 \\
(-0.67)\end{array}$ & $\begin{array}{l}0.001 \\
(1.33)\end{array}$ \\
\hline
\end{tabular}




\begin{tabular}{|c|c|c|c|c|c|c|c|}
\hline \multirow[t]{2}{*}{ Variables (in deviation, log form) } & \multicolumn{3}{|c|}{ Animal hours per ha } & \multicolumn{3}{|c|}{ Machine expenses per hectare } & \multirow{2}{*}{$\begin{array}{l}\text { Labour hour } \\
\text { Both } \\
\text { Phases } \\
\text { b/t } \\
\end{array}$} \\
\hline & $\begin{array}{l}\text { Both } \\
\text { Phases } \\
\text { b/t } \\
\end{array}$ & $\begin{array}{l}\text { Phase } 1 \\
\text { b/t }\end{array}$ & $\begin{array}{l}\text { Phase } 2 \\
\text { b/t }\end{array}$ & $\begin{array}{l}\text { Both } \\
\text { Phases } \\
\text { b/t } \\
\end{array}$ & $\begin{array}{l}\text { Phase } 1 \\
\text { b/t }\end{array}$ & $\begin{array}{l}\text { Phase } 2 \\
\text { b/t }\end{array}$ & \\
\hline Per Capita State Domestic Product & $\begin{array}{l}-0.000 \\
(-1.21)\end{array}$ & $\begin{array}{l}0.000 \\
(0.75)\end{array}$ & $\begin{array}{l}-0.000^{*} \\
(-2.06)\end{array}$ & $\begin{array}{l}-0.000 \\
(-0.46)\end{array}$ & $\begin{array}{l}-0.000 \\
(-0.86)\end{array}$ & $\begin{array}{l}0.000 \\
(0.64)\end{array}$ & $\begin{array}{l}-0.000 \\
(-0.98)\end{array}$ \\
\hline Annual Average Rainfall & $\begin{array}{l}-0.153 \\
(-0.70)\end{array}$ & $\begin{array}{l}-0.104 \\
(-0.49)\end{array}$ & $\begin{array}{l}-0.039 \\
(-0.10)\end{array}$ & $\begin{array}{l}-0.108 \\
(-0.49)\end{array}$ & $\begin{array}{l}-0.518 \\
(-0.68)\end{array}$ & $\begin{array}{l}-0.135 \\
(-0.84)\end{array}$ & $\begin{array}{l}0.110 \\
(1.41) \\
\end{array}$ \\
\hline Constant & $\begin{array}{l}1.847 \\
(1.33)\end{array}$ & $\begin{array}{l}0.421 \\
(0.12)\end{array}$ & $\begin{array}{l}-6.334 \\
(-0.95)\end{array}$ & $\begin{array}{l}-6.280^{* *} \\
(-3.23)\end{array}$ & $\begin{array}{l}-11.712 \\
(-1.72)\end{array}$ & $\begin{array}{l}-2.720 \\
(-0.84)\end{array}$ & $\begin{array}{l}-0.363 \\
(-0.74)\end{array}$ \\
\hline
\end{tabular}

$b$ refers to coefficient and trefers to $t$-value (in parenthesis) 


\section{APPENDIX TABLE 4 (Continued)}

\begin{tabular}{|c|c|c|c|c|c|c|}
\hline \multirow[t]{3}{*}{ Variables (in deviation, log form) } & \multicolumn{3}{|c|}{ Tractor sale } & \multicolumn{3}{|c|}{ Pumpsets } \\
\hline & \multicolumn{3}{|l|}{ Both } & \multicolumn{3}{|l|}{ Both } \\
\hline & $\begin{array}{l}\text { Phases } \\
\text { b/t }\end{array}$ & $\begin{array}{l}\text { Phase } 1 \\
\text { b/t }\end{array}$ & $\begin{array}{l}\text { Phase } 2 \\
\text { b/t }\end{array}$ & $\begin{array}{l}\text { Phases } \\
\text { b/t }\end{array}$ & $\begin{array}{l}\text { Phase } 1 \\
\text { b/t }\end{array}$ & $\begin{array}{l}\text { Phase } 2 \\
\text { b/t }\end{array}$ \\
\hline Credit & $\begin{array}{l}1.079 * * * \\
(3.32)\end{array}$ & $\begin{array}{l}0.096 \\
(0.18)\end{array}$ & $\begin{array}{l}1.671^{* *} \\
(3.11)\end{array}$ & $\begin{array}{l}-0.842 \\
(-1.52)\end{array}$ & $\begin{array}{l}0.038 \\
(0.03)\end{array}$ & $\begin{array}{l}-0.832 \\
(-0.82)\end{array}$ \\
\hline "Error" from Control function & $\begin{array}{l}-0.025 \\
(-0.07)\end{array}$ & $\begin{array}{l}0.347 \\
(0.45)\end{array}$ & $\begin{array}{l}0.040 \\
(0.08)\end{array}$ & $\begin{array}{l}-0.067 \\
(-0.08)\end{array}$ & $\begin{array}{l}-1.084 \\
(-0.62)\end{array}$ & $\begin{array}{l}-0.557 \\
(-0.48)\end{array}$ \\
\hline Net Sown Area & $\begin{array}{l}-0.094 \\
(-0.13)\end{array}$ & $\begin{array}{l}0.297 \\
(0.20)\end{array}$ & $\begin{array}{l}0.562 \\
(0.26)\end{array}$ & $\begin{array}{l}0.778 \\
(0.38)\end{array}$ & $\begin{array}{l}-1.698 \\
(-0.56)\end{array}$ & $\begin{array}{l}5.586 \\
(1.04)\end{array}$ \\
\hline Area under non-food Crops & $\begin{array}{l}0.000 \\
(0.72)\end{array}$ & $\begin{array}{l}-0.000 \\
(-0.62)\end{array}$ & $\begin{array}{l}0.000 \\
(0.92)\end{array}$ & $\begin{array}{l}-0.000 \\
(-0.36)\end{array}$ & $\begin{array}{l}-0.000 \\
(-0.37)\end{array}$ & $\begin{array}{l}-0.000 \\
(-0.23)\end{array}$ \\
\hline Index of Fertilizer/Pesticide prices & & & & $\begin{array}{l}0.048 \\
(0.83)\end{array}$ & $\begin{array}{l}0.456 \\
(1.58)\end{array}$ & $\begin{array}{l}0.009 \\
(0.05)\end{array}$ \\
\hline Wholesale Price Index & $\begin{array}{l}-0.054^{* *} \\
(-2.85)\end{array}$ & $\begin{array}{l}-0.013 \\
(-0.09)\end{array}$ & $\begin{array}{l}-0.000 \\
(-0.00)\end{array}$ & $\begin{array}{l}0.007 \\
(0.15)\end{array}$ & $\begin{array}{l}-0.477 \\
(-1.74)\end{array}$ & $\begin{array}{l}0.041 \\
(0.18)\end{array}$ \\
\hline Lagged Food Articles Price Index & $\begin{array}{l}0.012 \\
(1.33)\end{array}$ & $\begin{array}{l}-0.129 \\
(-0.70)\end{array}$ & $\begin{array}{l}0.040 \\
(0.60)\end{array}$ & $\begin{array}{l}-0.029 \\
(-1.13)\end{array}$ & $\begin{array}{l}0.310 \\
(0.79)\end{array}$ & $\begin{array}{l}-0.040 \\
(-0.31)\end{array}$ \\
\hline Tractor price index & $\begin{array}{l}-0.007 \\
(-0.33)\end{array}$ & $\begin{array}{l}0.133 \\
(0.92)\end{array}$ & $\begin{array}{l}-0.109 \\
(-1.74)\end{array}$ & & & \\
\hline Unskilled workers wage index & $\begin{array}{l}0.005 \\
(1.02)\end{array}$ & $\begin{array}{l}0.013 \\
(0.89)\end{array}$ & $\begin{array}{l}0.004 \\
(0.31)\end{array}$ & $\begin{array}{l}-0.002 \\
(-0.16)\end{array}$ & $\begin{array}{l}0.025 \\
(0.76)\end{array}$ & $\begin{array}{l}-0.010 \\
(-0.37)\end{array}$ \\
\hline Fule and Power price index & $\begin{array}{l}0.004 \\
(1.56)\end{array}$ & $\begin{array}{l}0.010 \\
(0.94)\end{array}$ & $\begin{array}{l}-0.055 \\
(-0.87)\end{array}$ & $\begin{array}{l}-0.001 \\
(-0.16)\end{array}$ & $\begin{array}{l}-0.076 \\
(-1.91)\end{array}$ & $\begin{array}{l}0.007 \\
(0.09)\end{array}$ \\
\hline (LAGGED) SHARE OF TOTAL VALU & F AGRICUI & URAL OUT & & & & \\
\hline Fibres & $\begin{array}{l}-0.002 \\
(-0.59)\end{array}$ & $\begin{array}{l}-0.002 \\
(-0.30)\end{array}$ & $\begin{array}{l}-0.004 \\
(-0.59)\end{array}$ & $\begin{array}{l}-0.002 \\
(-0.44)\end{array}$ & $\begin{array}{l}0.004 \\
(0.40)\end{array}$ & $\begin{array}{l}-0.005 \\
(-0.38)\end{array}$ \\
\hline Spices & $\begin{array}{l}0.009 \\
(1.51)\end{array}$ & $\begin{array}{l}0.013 \\
(1.03)\end{array}$ & $\begin{array}{l}0.004 \\
(0.32)\end{array}$ & $\begin{array}{l}-0.009 \\
(-0.51)\end{array}$ & $\begin{array}{l}-0.003 \\
(-0.14)\end{array}$ & $\begin{array}{l}-0.016 \\
(-0.48)\end{array}$ \\
\hline Cereals & $\begin{array}{l}-0.001 \\
(-1.01)\end{array}$ & $\begin{array}{l}-0.002 \\
(-0.69)\end{array}$ & $\begin{array}{l}-0.003 \\
(-0.82)\end{array}$ & $\begin{array}{l}-0.001 \\
(-0.23)\end{array}$ & $\begin{array}{l}0.001 \\
(0.16)\end{array}$ & $\begin{array}{l}-0.003 \\
(-0.47)\end{array}$ \\
\hline Fruits & $\begin{array}{l}0.000 \\
(0.21)\end{array}$ & $\begin{array}{l}0.003 \\
(1.11)\end{array}$ & $\begin{array}{l}-0.003 \\
(-0.72)\end{array}$ & $\begin{array}{l}-0.003 \\
(-0.76)\end{array}$ & $\begin{array}{l}-0.007 \\
(-0.84)\end{array}$ & $\begin{array}{l}-0.000 \\
(-0.00)\end{array}$ \\
\hline Oilseeds & $\begin{array}{l}0.001 \\
(0.66)\end{array}$ & $\begin{array}{l}-0.000 \\
(-0.10)\end{array}$ & $\begin{array}{l}-0.003 \\
(-0.66)\end{array}$ & $\begin{array}{l}-0.001 \\
(-0.32)\end{array}$ & $\begin{array}{l}-0.002 \\
(-0.44)\end{array}$ & $\begin{array}{l}0.001 \\
(0.05)\end{array}$ \\
\hline Pulses & $\begin{array}{l}0.004 \\
(1.45)\end{array}$ & $\begin{array}{l}0.005 \\
(0.74)\end{array}$ & $\begin{array}{l}-0.000 \\
(-0.02)\end{array}$ & $\begin{array}{l}-0.008 \\
(-1.17)\end{array}$ & $\begin{array}{l}-0.002 \\
(-0.20)\end{array}$ & $\begin{array}{l}-0.005 \\
(-0.22)\end{array}$ \\
\hline Sugar & $\begin{array}{c}-0.008^{*} \\
(-2.54)\end{array}$ & $\begin{array}{l}-0.009 \\
(-1.24) \\
\end{array}$ & $\begin{array}{l}-0.012 \\
(-1.87) \\
\end{array}$ & $\begin{array}{l}0.015^{*} \\
(2.39)\end{array}$ & $\begin{array}{l}0.015 \\
(1.18) \\
\end{array}$ & $\begin{array}{l}0.017 \\
(1.31) \\
\end{array}$ \\
\hline Per Capita State Domestic Product & $\begin{array}{l}0.000^{*} \\
(2.02)\end{array}$ & $\begin{array}{l}0.000 \\
(0.08)\end{array}$ & $\begin{array}{l}0.000 \\
(1.18)\end{array}$ & $\begin{array}{l}0.000^{* *} \\
(3.03)\end{array}$ & $\begin{array}{l}0.000^{*} \\
(2.03)\end{array}$ & $\begin{array}{l}0.000 \\
(1.32)\end{array}$ \\
\hline Annual Average Rainfall & $\begin{array}{l}0.226 \\
(1.21)\end{array}$ & $\begin{array}{l}0.195 \\
(0.39)\end{array}$ & $\begin{array}{l}-0.217 \\
(-0.45)\end{array}$ & $\begin{array}{l}-0.393 \\
(-0.95)\end{array}$ & $\begin{array}{l}0.529 \\
(0.63)\end{array}$ & $\begin{array}{l}-0.484 \\
(-0.64)\end{array}$ \\
\hline Constant & $\begin{array}{l}4.835^{*} \\
(2.54)\end{array}$ & $\begin{array}{l}1.170 \\
(0.11)\end{array}$ & $\begin{array}{l}12.919 * \\
(2.17)\end{array}$ & $\begin{array}{l}-1.789 \\
(-0.48)\end{array}$ & $\begin{array}{l}-20.078 \\
(-1.19)\end{array}$ & $\begin{array}{l}-1.878 \\
(-0.12)\end{array}$ \\
\hline
\end{tabular}


APPENDIX 5: Results for Agricultural GDP as part of SURE Model 3

\begin{tabular}{|c|c|c|c|}
\hline Variable (in log devation form) & $\begin{array}{l}\text { Both Phases } \\
\text { b/t }\end{array}$ & $\begin{array}{l}\text { Phase } 1 \\
\text { b/t }\end{array}$ & $\begin{array}{l}\text { Phase } 2 \\
\text { b/t }\end{array}$ \\
\hline Credit & $\begin{array}{l}0.083 \\
(1.00)\end{array}$ & $\begin{array}{l}-0.095 \\
(-0.39)\end{array}$ & $\begin{array}{l}0.133 \\
(0.77)\end{array}$ \\
\hline "Error" from Control Function & $\begin{array}{l}-0.028 \\
(-0.42)\end{array}$ & $\begin{array}{l}-0.130 \\
(-0.37)\end{array}$ & $\begin{array}{l}-0.042 \\
(-0.37)\end{array}$ \\
\hline Milk production & $\begin{array}{l}0.000 \\
(0.52)\end{array}$ & $\begin{array}{l}0.000 \\
(0.95)\end{array}$ & $\begin{array}{l}-0.000 \\
(-0.18)\end{array}$ \\
\hline Egg production & $\begin{array}{l}0.000 \\
(1.43)\end{array}$ & $\begin{array}{l}0.000 \\
(0.47)\end{array}$ & $\begin{array}{l}0.000 \\
(0.10)\end{array}$ \\
\hline Gross cropped area & $\begin{array}{l}0.193 \\
(0.92)\end{array}$ & $\begin{array}{l}0.186 \\
(0.44)\end{array}$ & $\begin{array}{l}-0.124 \\
(-0.18)\end{array}$ \\
\hline Land irrigated by canals & $\begin{array}{l}0.010 \\
(0.41)\end{array}$ & $\begin{array}{l}0.044 \\
(0.65)\end{array}$ & $\begin{array}{l}-0.017 \\
(-0.21)\end{array}$ \\
\hline Land irrigated by tanks & $\begin{array}{l}0.011 \\
(0.36)\end{array}$ & $\begin{array}{l}0.002 \\
(0.03)\end{array}$ & $\begin{array}{l}0.030 \\
(0.32)\end{array}$ \\
\hline Area under Non-food crops & $\begin{array}{l}-0.000 \\
(-0.63)\end{array}$ & $\begin{array}{l}-0.000 \\
(-0.07)\end{array}$ & $\begin{array}{l}0.000 \\
(0.11)\end{array}$ \\
\hline Pesticide & $\begin{array}{l}0.010 \\
(0.31)\end{array}$ & $\begin{array}{l}0.032 \\
(0.32)\end{array}$ & $\begin{array}{l}-0.045 \\
(-0.43)\end{array}$ \\
\hline Fertilizers (N, P and $\mathrm{K})$ & $\begin{array}{l}0.492^{* *} \\
(2.82)\end{array}$ & $\begin{array}{l}0.745^{*} \\
(2.42)\end{array}$ & $\begin{array}{l}0.184 \\
(0.66)\end{array}$ \\
\hline Tractors & $\begin{array}{l}-0.073 \\
(-1.32)\end{array}$ & $\begin{array}{l}-0.005 \\
(-0.04)\end{array}$ & $\begin{array}{l}-0.101 \\
(-0.69)\end{array}$ \\
\hline Pumpsets & $\begin{array}{l}-0.210 \\
(-1.16)\end{array}$ & $\begin{array}{l}0.033 \\
(0.07)\end{array}$ & $\begin{array}{l}-0.074 \\
(-0.18)\end{array}$ \\
\hline Labour hours per hectare & $\begin{array}{l}0.265^{* *} \\
(3.12)\end{array}$ & $\begin{array}{l}0.216 \\
(0.99)\end{array}$ & $\begin{array}{l}0.350 \\
(1.95)\end{array}$ \\
\hline Aimal hours per hectare & $\begin{array}{l}-0.040 \\
(-1.20)\end{array}$ & $\begin{array}{l}-0.043 \\
(-0.32)\end{array}$ & $\begin{array}{l}-0.017 \\
(-0.26)\end{array}$ \\
\hline Machine (Rs. Per hectare) & $\begin{array}{l}-0.001 \\
(-0.02)\end{array}$ & $\begin{array}{l}0.014 \\
(0.14)\end{array}$ & $\begin{array}{l}-0.003 \\
(-0.02)\end{array}$ \\
\hline Lagged unskilled wage index & $\begin{array}{l}0.001 \\
(0.96)\end{array}$ & $\begin{array}{l}-0.000 \\
(-0.09)\end{array}$ & $\begin{array}{l}0.002 \\
(0.49)\end{array}$ \\
\hline Average Annual Rainfall & $\begin{array}{l}-0.016 \\
(-0.33)\end{array}$ & $\begin{array}{l}-0.032 \\
(-0.24)\end{array}$ & $\begin{array}{l}-0.025 \\
(-0.26)\end{array}$ \\
\hline Lagged Fertilizer and Pesticide price index & $\begin{array}{l}0.020^{* *} \\
(3.28)\end{array}$ & $\begin{array}{l}0.071 \\
(0.99)\end{array}$ & $\begin{array}{l}0.161 \\
(0.58)\end{array}$ \\
\hline Lagged Fodder price index & $\begin{array}{l}0.002 \\
(1.42)\end{array}$ & $\begin{array}{l}0.003 \\
(1.23)\end{array}$ & $\begin{array}{l}-0.019 \\
(-0.52)\end{array}$ \\
\hline Lagged tractor price index & $\begin{array}{l}-0.006 \\
(-0.74)\end{array}$ & $\begin{array}{l}-0.019 \\
(-0.56)\end{array}$ & $\begin{array}{l}0.011 \\
(0.24)\end{array}$ \\
\hline Lagged Fuel and power price index & $\begin{array}{l}-0.003^{* *} \\
(-2.69)\end{array}$ & $\begin{array}{l}-0.012 \\
(-0.77)\end{array}$ & $\begin{array}{l}-0.011 \\
(-0.58)\end{array}$ \\
\hline
\end{tabular}




\begin{tabular}{llll}
\hline Variable (in log devation form) & $\begin{array}{l}\text { Both Phases } \\
\mathbf{b} / \mathbf{t}\end{array}$ & $\begin{array}{l}\text { Phase 1 } \\
\text { b/t }\end{array}$ & $\begin{array}{l}\text { Phase 2 } \\
\text { b/t }\end{array}$ \\
\hline Wholesale Price Index & -0.006 & -0.015 & -0.028 \\
& $(-0.89)$ & $(-0.55)$ & $(-0.50)$ \\
Capital expenditure on economic services & -0.009 & -0.019 & -0.005 \\
& $(-0.80)$ & $(-0.64)$ & $(-0.25)$ \\
Capital expenditure on Agriculture and allied services & 0.000 & -0.001 & 0.001 \\
Revenue expenditure on agriculture and allied & $(0.06)$ & $(-0.14)$ & $(0.06)$ \\
services & & & \\
& 0.076 & -0.052 & 0.056 \\
Percentage of villages electrified & $(0.87)$ & $(-0.31)$ & $(0.49)$ \\
& -0.000 & 0.008 & -0.002 \\
Constant & $(-0.03)$ & $(0.78)$ & $(-0.34)$ \\
& -0.105 & 0.000 & -0.488 \\
N & $(-0.80)$ & $()$. & $(-0.37)$ \\
R-squared & 121.00 & 59.00 & 62.00 \\
BIC & 0.74 & 0.47 & 0.69 \\
AIC & 603.77 & 411.02 & 324.76 \\
\hline b refers to & 170.42 & 91.08 & -4.948 \\
\hline
\end{tabular}

$b$ refers to coefficient and $t$ refers to $t$-value (in parenthesis) 
APPENDIX 6: Regional distribution of agriculture credit and real sector indicators

\begin{tabular}{|c|c|c|c|c|c|c|c|}
\hline \multirow[b]{2}{*}{ Regions } & \multicolumn{2}{|c|}{$\begin{array}{l}\text { Flow of agriculture } \\
\text { credit }\end{array}$} & \multicolumn{5}{|c|}{ Real Sector Indicators } \\
\hline & $\begin{array}{l}\text { Av. Share } \\
\text { of agri. } \\
\text { credit } \\
\text { during } \\
\text { 10th } \\
\text { Plan } \\
\text { Period } \\
\end{array}$ & $\begin{array}{l}\text { Av. Share } \\
\text { of agri. } \\
\text { credit } \\
\text { during } \\
\text { 11th Plan } \\
\text { Period }\end{array}$ & $\begin{array}{l}\text { Share } \\
\text { in GCA }\end{array}$ & $\begin{array}{l}\text { Share } \\
\text { in GIA }\end{array}$ & $\begin{array}{l}\text { Cropping } \\
\text { Intensity }\end{array}$ & $\begin{array}{l}\text { Av. Share in } \\
\text { Food grain } \\
\text { production\# }\end{array}$ & $\begin{array}{l}\text { Distribution } \\
\text { of Rural and } \\
\text { semi urban } \\
\text { branches of } \\
\text { Commercial } \\
\text { Banks(\%) }\end{array}$ \\
\hline Northern & 28.69 & 26.01 & 20.11 & 26.32 & 148 & 26.58 & 16.62 \\
\hline $\begin{array}{l}\text { North } \\
\text { Eastern }\end{array}$ & 0.38 & 0.62 & 2.83 & 0.68 & 128 & 2.02 & 3.16 \\
\hline Eastern & 6.67 & 7.54 & 14.65 & 15.25 & 151 & 16.37 & 17.99 \\
\hline Central & 15.1 & 12.58 & 27.26 & 31.66 & 139 & 30.55 & 21.51 \\
\hline Western & 14.17 & 13.33 & 16.47 & 9.74 & 114 & 8.31 & 12.98 \\
\hline Southern & 34.99 & 39.92 & 18.68 & 16.35 & 124 & 16.17 & 27.74 \\
\hline Total & 100 & 100 & 100 & 100 & & 100 & 100 \\
\hline
\end{tabular}

Note: (a) \# denotes average share for the period 2008-09 to 2012-13.

(b) GCA- Gross Cropped Area, GIA- Gross irrigated Area. GCA and GIA are averages for the period 2007-08 to 2011-12.

(c) Distribution of branches calculated from Statistical Tables Relating to Banks in India, RBI Source: Calculated based on data from MOA, RBI, IBA and NABARD 